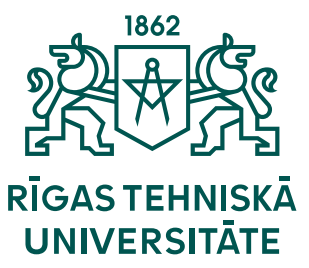

Alisa Koroḷova

\title{
LIELMËROGA DZĪVOJAMO RAJONU ĀRTELPAS TRANSFORMĀCIJAS RĪGĀ POSTSOCIĀLISMA PERIODĀ
}

Promocijas darba kopsavilkums

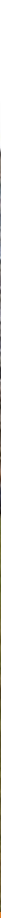




\title{
RĪGAS TEHNISKĀ UNIVERSITĀTE \\ Arhitektūras fakultāte \\ Arhitektūras projektēšanas katedra
}

\section{Alisa Koroḷova}

Doktora studiju programmas

"Arhitektūra" doktorante

\section{LIELMĒROGA DZĪVOJAMO RAJONU ĀRTELPAS TRANSFORMĀCIJAS RĪGĀ POSTSOCIĀLISMA PERIODĀ}

Promocijas darba kopsavilkums

\author{
Zinātniskā vadītāja \\ profesore Dr. arch. \\ SANDRA TREIJA
}

RTU Izdevniecība

Rīga 2021 
Koroḷova, A. Lielmēroga dzīvojamo rajonu ārtelpas transformācijas Rīgā postsociālisma periodā. Promocijas darba kopsavilkums. Rīga: RTU Izdevniecība, 2021. - 54 lpp.

Iespiests saskan̄ā ar promocijas padomes "RTU P-10" 2021. gada 21. jūnija lēmumu, protokols Nr. 04030-9.10.2/1.

https://doi.org/10.7250/9789934226946

ISBN 978-9934-22-694-6 (pdf) 


\section{PROMOCIJAS DARBS IZVIRZĪTS ZINĀTNES \\ DOKTORA GRĀDA IEGŪŠANAI \\ RĪGAS TEHNISKAJĀ UNIVERSITĀTĒ}

Promocijas darbs zinātnes doktora $(P h . D$.) grāda iegūšanai tiek publiski aizstāvēts 2021. gada 17. novembrī plkst. 10 Rīgas Tehniskās universitātes Arhitektūras fakultātē (attālināti).

\section{OFICIĀLIE RECENZENTI}

Profesore Dr. arch. Aija Ziemel̦niece,

Latvijas Lauksaimniecības universitāte, Latvija

Asociētā profesore Ph. D. Indre Gražulevičiūte-Vileniške (Indré Gražulevičiūté-Vilenišké),

Kauņas Tehnoloǵiju universitāte, Lietuva

Profesors Ph. D. Gintars Stausks (Gintaras Stauskis), Viḷnas G̦edimina tehniskā universitāte, Lietuva

\section{APSTIPRINĀJUMS}

Apstiprinu, ka esmu izstrādājusi šo promocijas darbu, kas iesniegts izskatīšanai Rīgas Tehniskajā universitātē zinātnes doktora (Ph. D.) grāda iegūšanai. Promocijas darbs zinātniskā grāda iegūšanai nav iesniegts nevienā citā universitātē.

Alisa Korolova (paraksts)

Datums:

Promocijas darbs ir uzrakstīts angḷu valodā, tajā ir ievads, trīs nodaḷas, 12 secinājumu, literatūras saraksts, 54 attēli, sešas tabulas, pieci pielikumi, kopā 124 lappuses, neieskaitot pielikumus. Literatūras sarakstā ir 262 nosaukumi. 


\section{SATURS}

IEVADS .......................................................................................................... 5

1. LIELMĒROGA DZĪVOJAMO RAJONU ĀRTELPAS

ATTİSTİBA EIROPĀ

16

1.1. Ārtelpas genēze un raksturs lielmēroga

dzìvojamos rajonos ........................................................................... 16

1.2. Ārtelpas loma iedzīvotāju vajadzību apzināšanā .................................. 17

1.3. Lielmēroga dzīvojamo rajonu ārtelpas loma pilsētu zaḷās infrastruktūras sistēmā

2. LIELMĒROGA DZĪVOJAMO RAJONU DZĪVOJAMĀS VIDES KVALITĀTE UN ĀRTELPAS TRANSFORMĀCIJAS 19

2.1. Lielmēroga dzīvojamo rajonu ārtelpas transformācijas Eiropā 19

2.2. Dzīvojamās vides kvalitātes koncepts un vērtēšanas metodes 21

2.3. Ārtelpas transformāciju ietekmes uz dzīvojamās vides kvalitāti vērtēšana

3. RİGAS LIELMĒROGA DZĪVOJAMO RAJONU ĀRTELPAS TRANSFORMĀCIJU IETEKME UZ DZĪVOJAMĀS VIDES KVALITĀTI 25

3.1. Lielmēroga dzīvojamo rajonu ārtelpas rakstura iezīmes 25

3.2. Ārtelpas kvalitātes transformācijas lielmēroga dzīvojamos rajonos 25

3.3. Kopsakarības starp iedzīvotāju viedokli un ārtelpas transformācijām 26

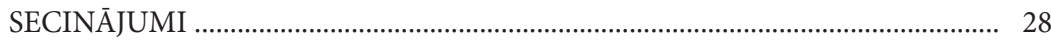

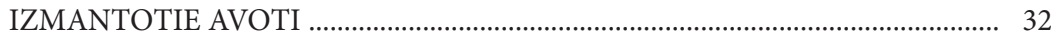




\section{IEVADS}

Ārtelpa lielmēroga dzīvojamos rajonos ir nozīmīga dzīvojamās vides kvalitātes sastāvdal̦a, kas nodrošina dažāda veida funkciju izpildi. Apzal̦umota ārtelpa ir viena no lielmēroga dzīvojamo rajonu raksturīgām iezīmēm, ko daudzi iedzīvotāji uztver kā visvērtīgāko dzīvojamās vides kvalitāti [49], [127], [162], [143]. Postsociālisma periodā lielmēroga dzīvojamo rajonu ārtelpa ir tikusi pakḷauta dažāda veida transformācijām. Latvijā par šo transformāciju sākumpunktu var uzskatīt izmaiṇas politiskajā situācijā, kas veicināja zemes reformu, kā arī izmaiṇas ārtelpas uzturēšanas un apsaimniekošanas model̦os. Zemes reforma un īpašuma denacionalizācija 20. gadsimta 90. gados [257] veicināja pašreizējo sarežǵīto situāciju lielmēroga dzīvojamos rajonos, kur zemes vienības ir sadrumstalotas, kā arī īpašnieki zemei un ēkām ir dažādi. Šobrīd transformācijas procesus ietekmē arī mainīgie ekonomiskie, ekoloǵiskie un sociālie faktori. Valsts un pilsētas līmeņa stratēgijas, kuru mērķis ir ilgtspējīga kompakta attīstība, privātā sektora spiediens, globālā izpratne par ekoloǵiskiem jautājumiem, pieaugoša iedzīvotāju interese līdzdarboties un ietekmēt pilsētplānošanas un pilsētveidošanas procesus, jauni sadarbības un pārvaldības model̦i un citi faktori ietekmē izmaiṇas lielmēroga dzīvojamo rajonu ārtelpas uztverē, darbībā un attīstībā.

Transformāciju veids ir izšķirošais aspekts, kas var veicināt gan pozitīvas, gan negatīvas pārmaiņas lielmēroga dzīvojamo rajonu ārtelpā. Gadījumos, kad transformācijas veicina dzīvojamās vides kvalitātes pasliktināšanos, tās var kalpot kā virzītājspēks, kas veicina iedzīvotāju pārcelšanos uz citu dzīvesvietu. Šādā situācijā lielmēroga dzīvojamā rajonā paliek iedzīvotāju grupas, kas dažādu iemeslu dēl nevar atl̦auties mainīt savu dzīvesvietu (piemēram, gados vecāki iedzīvotāji, sociālās grupas ar zemu ienākumu līmeni u. tml.). Savukārt pozitīvas transformācijas var veicināt īpašuma vērtības paaugstināšanos un jaunu iedzīvotāju pieplūdumu.

Rīgā lielmēroga dzīvojamie rajoni, kur šobrīd dzīvo aptuveni 60 \% iedzīvotāju, joprojām veido lielu dzīvojamā fonda daḷu. Pieaugošais jauno mājokḷu tirgus rada konkurenci lielmēroga dzīvojamiem rajoniem, tādējādi palielinot nepieciešamību pēc dzīvojamas vides 
kvalitātes uzlabošanas, kas veicinātu iedzīvotāju vēlmi par ilgtermiṇa dzīvesvietu izvēlēties lielmēroga dzīvojamos rajonus.

Lielmēroga dzìvojamo rajonu publiskās ārtelpas transformācijas var iedalīt fiziskās, sociālās un juridiskās. Fiziskām transformācijām piemīt dažāds mērogs: mikromērogs (viena pagalma vai pat mazāks mērogs), mezomērogs (mikrorajons vai lielmēroga dzīvojamais rajons), makromērogs (pilsētas mērogā, piemēram, integrējot lielmēroga dzīvojamā rajona ārtelpu pilsētas zalıjā infrastruktūrā). Šīs transformācijas ietver labiekārtojumu, ārtelpas detalıiekārtas, apstādījumu ierīkošanu, infrastruktūras uzlabojumus, kā arī jaunās apbūves integrāciju, kas veicina ārtelpas platības un rakstura izmaiṇas. Sociālās transformācijas ietver izmaiṇas iedzīvotāju demogrāfiskajā struktūrā. Šis transformācijas izraisa gan sabiedrības novecošanās, gan demogrāfiskās izmain,as, kas saistītas ar mājsaimniecību izmēra sarukšanu, mazo mājsaimniecību skaita pieaugumu utt. [107]. Turklāt izmaiṇas likumdošanā ietekmē transformācijas zemes īpašumtiesībās, apsaimniekošanas un pārvaldības modelıs.

Transformācijas lielmēroga dzīvojamo rajonu ārtelpā var tikt iedalītas ne tikai pēc mēroga, bet arī pēc to virzītājspēka un iesaistītajiem dalībniekiem. Transformāciju un to ietekmes uz dzīvojamās vides kvalitāti pētījumos nozīmīgs aspekts ir visu tieši un netieši iesaistīto pušu apzināšana. Izšksir ārēji vadītas ārtelpas transformācijas un transformācijas ar pašorganizēto iesaisti. Pastāv gan nelielas ietekmes transformācijas, piemēram, jaunu ārtelpas detaḷiekārtu izbūve rekreācijai vai jaunu apstādījumu ieviešana, gan transformācijas, kas lielākā mērā ietekmē ārtelpas raksturu un izmantošanas iespējas, piemēram, automašīnu stāvvietu izveide vai jaunās dzīvojamās apbūves integrācija. Šo transformāciju mērķauditorija ir šaura, un daudzu citu iedzīvotāju grupu vēlmes un vajadzìbas netiek nuemtas vērā. Tas var veicināt konfliktus starp dažādām iedzīvotāju grupām, tajā skaitā starppaaudžu konfliktus [49, 137]. Dzīvojamai mājai piegulošā ārtelpa ir svarīga gados vecākiem cilvēkiem un cilvēkiem ar īpašām vajadzībām. Šìs iedzīvotāju grupas ir atkarīgas no ārtelpas, kas ir viṇu mājas tiešā tuvumā, un tās ārtelpas kvalitāte tiešā veidā ietekmē viṇu dzīves kvalitāti [182]. Arī bērniem un jauniešiem brīvā laika pavadīšanas iespējas ārtelpā ietekmē vinu veselību un dzīves kvalitāti. Rīgas lielmēroga dzīvojamos rajonos 
gan gados vecāki cilvēki, gan bērni un pusaudži veido nozīmīgu iedzīvotāju dal̦u. Piemēram, Imantas apkaimē 25 \% (11 215 cilvēki) iedzīvotāju ir vecuma grupā 65 gadi un vecāki, Purvciemā, Ilǵguciemā un Juglā šis skaitlis ir $23 \%$ no kopējā apkaimes iedzìvotāju skaita. Daudzos lielmēroga dzīvojamos rajonos bērni, pusaudži un jaunieši vecumā no 7 līdz 24 gadiem veido apmēram $16 \%$ no kopējā apkārtnes iedzīvotāju skaita [196]. Šìm dažādām grupām ir atšksirīgas vajadzības un vēlmes, un to apzināšanai ir liela nozīme dzīvojamās vides attīstībā.

Lielmēroga dzīvojamie rajoni veido nozīmīgu dzīvojamā fonda îpatsvaru Baltijas valstu galvaspilsētās. Pēc neatkarības atjaunošanas 1991. gadā Tallinā lielmērogā dzìvojamos rajonos dzīvoja 61 \% iedzīvotāju, savukārt Rīgā - 74 \% [19, 8]. Pēc 2011. gada statistiskiem rādītājiem 58 \% Tallinas iedzīvotāju, 75 \% Rīgas iedzìvotāju un 67 \% Viḷnas iedzīvotāju dzīvoja lielmērogā dzīvojamos rajonos $[19,8]$. Šì iemesla dēl Baltijas valstīs, kur iedzīvotāju īpatsvars lielmēroga dzīvojamos rajonos ir l̦oti liels, dzīvojamo ēku nojaukšana uzskatāma par sarežgìitu scenāriju. Līdz ar to izšķiroša nozīme šo pilsētas dal̦u ilgtermiṇa ilgtspējīgai attīstībai ir atjaunošanai un dzīvojamās vides kvalitātes celšanai.

\section{Tēmas līdzšinējais izpētes līmenis}

Ārtelpa lielmēroga dzīvojamos rajonos tiek pētīta no dažādiem skatupunktiem un dažādos kontekstos: gan publiskās ārtelpas funkcionēšanas kontekstā [34], [58], [117], [122], gan pētījumos par lielmēroga dzìvojamo rajonu rašanās iemesliem, gan definējot mūsdienu iespējas, izaicinājumus un attīstības tendences [19], [20], [42], [49], [58], gan pētījumos par pilsētas dzīves kvalitāti [36], [49], [67].

Lielmēroga dzīvojamo rajonu rašanās iemesli un attīstības vēsture analizēta gan Baltijas valstu kontekstā [11], [19], [26], [254], gan citās Eiropas valstīs [20], [49], [255]. Grāmatā "Housing estates in the Baltic countries" apkopoti vairāku pētnieku raksti, kuros sniegts ieskats par lielmēroga dzīvojamo rajonu telpiskās organizācijas principiem un to ietekmējošiem faktoriem, aprakstīta Ziemel̦eiropas valstu ietekme uz telpisko organizāciju un sabiedriskās funkcijas objektu izvietojumu [19]. RESTATE projektā apkopots nozīmīgs 
materiāls par vietējām īpatnībām lielmēroga dzīvojamo rajonu attīstībā [66], [143], [147].

Lielmēroga dzīvojamo rajonu ārtelpas raksturu un tās atbilstību iedzīvotāju vajadzībām sāka pētīt jau 20. gadsimta otrajā pusē vienlaikus ar jauno lielmēroga dzīvojamo rajonu attīstību [46], [127]. Lielmēroga dzìvojamo rajonu zaḷās ārtelpas lomu analizēja vairāki pētnieki [64], [65], [49]. Mūsdienās dzīves kvalitāti lielmēroga dzīvojamos rajonos un publiskās ārtelpas ietekmi uz sociālo kontaktu veidošanos un sociālo saliedētību pēta Ričards Sendi (Richard Sendi), Manuēls Ālbērs (Manuel Aalbers) un Marsels Trigero (Marcele Trigueiro) [49, 131-157], [66], [67]. Daudzi pētnieki ir pievērsušies nekustamo īpašumu denacionalizācijas un zemes reformas jautājumiem [42], [171].

Daudzviet Eiropā lielmēroga dzīvojamie rajoni saskaras ar dažāda veida izaicinājumiem, kas saistīti gan ar ēku un ārtelpas detaliekārtu, infrastruktūras fizisko novecošanos, gan sociālām izmaiņām. Jau 20. gadsimta nogalē pētnieki sāka pievērsties šo izaicinājumi izpētei, analizējot gan problēmu rašanas iemeslus, gan meklējot risinājumus [8], [46]. Nīderlandiešu pilsētplānotājs Oskars Nūmans (Oscar Newman) jau 20. gadsimta 70. gados aktīvi kritizēja lielmēroga rajonu ārtelpu [41]. Nīls Praks (Niels Prak) un Hugo Prīmus (Hugo Priemus) izstrādāja pēckara lielmēroga dzīvojamo rajonu pagrimuma teorētisko modeli, kas skaidroja sociālā, ekonomiskā un tehniskā pagrimuma kopsakarības [47]. 1993. gadā Henks Pēteris Hīgers (Henk Peter Heeger) papildināja šo modeli ar pilsētvides dizaina aspektiem: izvietojumu, dzīvojamo vidi, pakalpojumu līmeni. Ali Madanipurs (Ali Madanipour) pievērsās Eiropas lielmēroga dzīvojamo rajonu publiskās ārtelpas problēmu izpētei, definējot šo vidi kā "marginālu", kas nav vietējo pašvaldību prioritātē reǵenerācijas jautājumos. Tajā pašā laikā ārtelpa bija kḷuvusi par konflikta teritoriju, kurā saskārās iedzīvotāji ar dažādām interesēm un vajadzībām [29]. Metjū Karmona (Matthew Carmona) ir izstrādājis kompleksus publiskās ārtelpas kvalitātes vērtēšanas kritērijus [86], [87], [88]. Digitalizācija ḷauj meklēt jaunas pieejas lielmēroga dzīvojamo rajonu ārtelpas analīzei, izmantojot tādas metodes kā Space Syntax [190].

Arī mūsdienās lielmēroga dzīvojamo rajonu izaicinājumi un attīstība ir aktuāls jautājums. Daniels Hess (Daniel Hess) un Tìts 
Tammaru (Tiit Tammaru) definējuši četrus liemēroga dzīvojamo rajonu attīstības virzienus: "nedarīt neko", "samazināt aizṇemamo teritoriju, dal̦u no ēkam nojaucot" "nojaukt un aizvietot ar citu dzīvojamo apbūvi" vai "atjaunot" [19]. N,emot vērā to, ka Rīgā lielmēroga dzīvojamie rajoni veido ievērojamu dzīvojamā fonda dalıu, kas dominējoši ir saskaldīts mazos privātīpašumos, daḷēja vai pilnīga nojaukšana būtu sarežgìits, ilgtermiṇa process. Savukārt atjaunošana l̦autu paaugstināt dzīvojamās vides kvalitāti un iedzīvotāju apmierinātību ar dzīvi apkaimē.

Daudzi pētnieki ir atzinuši, ka lielmēroga dzīvojamo rajonu ārtelpā notiek konkrētas transformācijas, tomēr šobrīd trūkst pētījumu, kas apkopotu informāciju par dažādu ārtelpas transformāciju ietekmi uz dzīvojamās vides kvalitāti un piedāvātu metodologiju esošo un nākotnes transformāciju ietekmes uz dzīvojamās vides kvalitāti novērtējumam.

Pētījuma priekšmets ir lielmēroga dzīvojamo rajonu ārtelpas transformācijas.

Pētījuma mērķis ir izvērtēt lielmēroga dzìvojamo rajonu postsociālisma perioda ārtelpas transformāciju ietekmi uz dzīvojamās vides kvalitāti lielmēroga dzìvojamos rajonos Rīgā.

\section{Uzdevumi mērḳa sasniegšanai}

1. Apkopot un strukturēt informāciju par lielmēroga dzīvojamo rajonu ārtelpas plānošanas teorētiskām nostādnēm un realizētiem rezultātiem, dzīvojamo rajonu ārtelpas lomu pilsētas zaḷās infrastruktūras sistēmā un ārtelpas lomu iedzìvotāju vajadzību apzināšanā.

2. Izpētīt un apkopot informāciju par lielmēroga dzīvojamo rajonu ārtelpas transformāciju veidiem.

3. Noteikt iespējas un šksēršlus iedzīvotāju līdzdalībai rajonu ārtelpas transformācijas procesos.

4. Apkopot informāciju par dzīvojamās vides kvalitātes novērtēšanas pieejām un rīkiem.

5. Izstrādāt metodolog̣iju lielmēroga dzīvojamo rajonu ārtelpas transformāciju ietekmes uz dzīvojamās vides kvalitāti vērtēšanai. 
4. Izmantojot adaptēto ārtelpas kvalitātes vērtēšanas rīku, veikt Rīgas lielmēroga dzīvojamo rajonu publiskās ārtelpas apsekošanu, apkopot informāciju par transformāciju ietekmi uz dzīvojamās vides kvalitāti.

6. Izstrādāt un veikt iedzīvotāju aptauju, kas l̦aus iegūt datus par dažādu dzīvojamās vides faktoru nozīmi iedzīvotājiem, viṇu apmierinātību ar lielmēroga dzīvojamo rajonu ārtelpu kopumā un viņu uzskatiem par transformācijas procesu ietekmi uz dzīvojamās vides kvalitāti.

\section{Pētījumā izmantotās metodes}

Pētījuma teorētisko bāzi veido zinātniskā literatūra, recenzēti zinātniskie raksti, plānošanas un citi dokumenti, zinātnisko pētījumu un inovāciju projektu atskaites, nacionālie un starptautiskie tiešsaistes resursi.

Pamatojoties uz informācijas avotu teorētisko analīzi, veikts empīrisks pētījums, kurā izmantotas šādas metodes.

- Salīdzinošā analīze

- lielmēroga dzīvojamo rajonu ārtelpas attīstības vēstures un ārtelpas raksturu ietekmējošo faktoru izpētei.

- lielmēroga dzīvojamo rajonu ārtelpas transformāciju un ietekmējošo faktoru analīzei.

- Science direct un Scopus datubāzes zinātnisko rakstu izpētei, izmantojot PRISMA metodoloǵiju (1183 zinātniskie raksti).

- Pilsētvides novērtēšanas rīku izpētei.

- Eksperiments

- Novērtēt ārtelpas transformācijas atḷaujas iegūšanas procesu institūcijās.

- Novērtēt iedzìvotāju ieinteresētību dalībai ārtelpas aktivitātēs.

- Teritorijas kartēšana

- Pilsētvides apsekošanai.

- Rezultātu sistematizēšanai.

- Lielmēroga dzīvojamo rajonu iedzīvotāju aptauja ar dal̦ēji atvērtiem jautājumiem

- Iedzīvotāju viedokḷu noskaidrošanai (240 respondenti). 


\section{Darba zinātniskā novitāte}

Promocijas darbs dod ieguldījumu Rīgas lielmēroga dzīvojamo rajonu ārtelpas transformāciju izpētē, kas no ietekmes uz dzīvojamās vides kvalitāti skatupunkta ir maz pētīts. Darbā piedāvāta lielmērogā dzīvojamo rajonu ārtelpas klasifikācija, apkopoti dati par dzīvojamās vides kvalitātes vērtēšanas rīkiem, un izstrādāta metode notikušo un nākotnes transformāciju ietekmes uz dzīvojamās vides kvalitāti vērtējumam.

\section{Darba praktiskā nozīme}

Pētījumā apskatīta mūsdienās aktuālā problemātika, uzsverot lielmēroga dzīvojamo rajonu ārtelpas nozīmi un nepieciešamību apzināt transformāciju ietekmi uz dzīvojamās vides kvalitāti. Pētījums atklāj nozīmīgākos aspektus saistībā ar transformācijām ārtelpā.

Pētījums atklāj saistību starp transformācijām ārtelpā un dzīvojamās vides kvalitātes uzlabošanos vai pasliktināšanos. Izstrādātā vērtēšanas metode izmantojama gan notikušo transformāciju ietekmes uz dzīvojamās vides kvalitāti apzināšanai, gan nākotnes scenāriju vērtēšanai, lai nepiel̦autu lielmēroga dzīvojamo rajonu ārtelpas degradāciju un veicinātu dzīvojamās vides kvalitātes paaugstināšanos.

Promocijas darba secinājumi un ierosinājumi par transformāciju ietekmi uz dzīvojamās vides kvalitāti lielmērogā dzīvojamos rajonos izmantojami plānošanas vadlīniju izstrādei.

Attēli, kuru parakstos nav norādīts autors, ir pētījuma autores veidoti.

\section{Pētījuma rezultātu aprobācija}

Anonìmi recenzēti zinātniskie raksti starptautiskos zinātniskos žurnālos

1. Korolova, A., Treija, S. Spatial Character and Usage of Public Open Space in Large Housing Estates. Journal of Architecture and Urbanism, VGTU, Scopus (iesniegts publicēšanai 2021. gadā). 
2. Shih, Ch.-M., Treija, S., Zaleckis, K., Bratuškins, U., Chen, Ch.-H., Chen, Y.-H., Chiang, Ch.T.W., Jankauskaitė-Jurevičienė, L., Kamičaitytė, J., Koroḷova, A., Lee, H.-Ch., Lektauers, A., Mlinkauskienė, A. Digital Placemaking for Urban Regeneration: Identification of Historic Heritage Values in Taiwan and the Baltic States. Urban Planning, Special issue: Towards Digital Urban Regeneration: Embedding Digital Technologies into Urban Renewal Processes and Development, Vol. 6, Issue 4, 2021 (apstiprināts publicēšanai 2021. gadā).

3. Pearlmutter, D., Pucher, B., Calheiros, C.S.C., Hoffmann, K.A., Aicher, A., Pedro, P., Stracqualursi, A., Korolova, A., Pobric, A., Taieb, A.H., Galvão, A., Tokuç, A., Bas, B., Theochari, D., Milosevic, D., Giancola, E., Bertino, G., Lazarevic, J., Castellar, J., Flaszynska, J., Onur, M., Mateo, M.C.G., Andreucci, M.B., Milousi, M., Fonseca, M., Di Lonardo, S., Gezik, V., Pitha, U., Nehls, T. Closing Water Cycles in the Built Environment Through Nature-Based Solutions: The Contribution of Vertical Greening Systems and Green Roofs. Water, 13 (16), 2021, 2165. https://doi.org/10.3390/w13162165.

4. Bratuškins, U., Zaleckis, K., Treija, S., Koroḷova, A., Kamičaitytė, J. Digital Information Tools in Urban Regeneration: Capital's Approach in Theory and Practice. Sustainability, Vol. 12, No. 19, 2020, pp. 1-16. ISSN 2071-1050. https://doi.org/10.3390/SU12198082.

5. Pearlmutter, D., Theochari, D., Nehls, T., Pinho, P., Piro, P., Korolova, A., Papaefthimiou, S., Mateo, M. C. G., Calheiros, C., Zluwa, I., Pitha, U., Schosseler, P., Florentin, Y., Ouannou, S., Gal, E., Aicher, A., Arnold, K., Igondová, E., Pucher, B. Enhancing the Circular Economy with Nature-Based Solutions in the Built Urban Environment: Green Building Materials, Systems and Sites. Blue-Green Systems, Vol. 2, Issue 1, 2020, pp. 46-72. https://doi.org/10.2166/ bgs.2019.928.

6. Korolova, A., Treija, S. Participatory Budgeting in Urban Regeneration: Defining the Gap Between Formal and Informal Citizen Activism. Architecture and Urban Planning, Vol. 15, 2019, pp. 131-137. https://doi.org/10.2478/aup-2019-0018.

7. Korolova, A., Treija, S. Urban Gardening as a Multifunctional Tool to Increase Social Sustainability in the City. Architecture and Urban Planning, Vol. 14, Issue 1, 2018, pp. 91-95. https://doi.org/10.2478/ aup-2018-0012.

8. Treija, S., Bratuškins, U., Koroḷova, A. Urban Densification of Large Housing Estates In The Context Of Privatisation Of Public Open Space: The Case Of Imanta, Riga. Architecture and Urban Planning, Vol. 14, Issue 1, 2018. pp. 105-110. https://doi.org/10.2478/aup-2018-0014. 
Uzstāšanās ar referātu starptautiskās zinātniskās konferencēs un pilna teksta publikācijas konferenču materiālu izdevumos

1. Treija, S., Bratuškins, U., Koroḷova, A. Up-to-Date Interventions and Changing Identity: Housing Estate Imanta in Riga. Proceedings of the $15^{\text {th }}$ international Docomomo Conference, Metamorphosis The continuity of change, Slovēnija. Lubl̦ana, 2018. gada 28.-31. augustā, pp. 174-180.

https://issuu.com/docomomo_si/docs/1_pdfsam_docomomo_layout_ebook.

2. Korolova, A., Treija, S. The Diverse Nature of Local Activism Trends and its Impact on the Quality of Life in the City. AESOP Congress: Making space for hope, Conference proceedings, Zviedrija, Gēteborga, 2018. gada 10.-14. jūlijā.

3. Korolova, A., Treija, S. The Impact of Land-Use on The Social and Ecological Systems In Courtyards of Large Scale Housing Estates. $17^{\text {th }}$ International Multidisciplinary Scientific GeoConference SGEM 2017, www.sgemviennagreen.org, SGEM2017 Vienna GREEN Conference Proceedings, ISBN 978-619-7408-29-4 / ISSN 1314-2704, Austrija, Vīne, 2017. gada 27.-29. novembrī. Vol. 17, Issue 63, pp. 1039-1046. https://doi.org/10.5593/sgem2017h/63/s27.129.

4. Korolova, A., Treija, S. Community Gardens as Temporary Uses for Vacant Land Revitalization: the Case of Riga. In: Spaces of Dialog for Places of Dignity: Fostering the European Dimension of Planning : Lisbon AESOP Annual Congress 2017 : Book of Proceedings, Portugāle, Lisabona, 2017. gada 11.-14. jūlijā. Lisboa: Universidade de Lisboa, 2017, pp. 444-449. e-ISBN 978-989-99801-3-6.

5. Treija, S., Koroḷova, A., Latkowska, M. Environmental Design Solutions to Promote Safety in Urban Gardens. Growing in Cities. Interdisciplinary Perspectives on Urban Gardening: Conference Proceedings, Šveice, Bāzele, 2016. gada 10.-11. septembrī. Basel: University of Applied Sciences, 2016, pp. 180.-197. ISBN 978-3-033-05757-9.

Uzstāšanās ar referātu starptautiskās zinātniskās konferencēs

1. Korolova, A., Treija, S. Public Open Space Transformations in Large Housing Estates. 2021. gada 9. martā, tiešsaistē. COST Action European Middle Class Mass Housing Conference / WG-Meeting.

2. Treija, S., Korolova, A. Collaborative Housing: an Innovation for Neighbourhood Development. LU 79. Starptautiskā zinātniskā conference: Telpiskā plānošana ar skatījumu uz nākotnes dzīves veidu un mājokli / Spatial planning and an outlook on future housing and lifestyle. 2021. gada 19. martā, tiešsaistē. 
3. Treija, S., Bratuškins, U., Koroḷova, A., Lektauers, A. Participatory Budgeting for Urban Regeneration in Riga. The Second Online Conference Smart City (MUTUAL FUNDS TAIWAN - LATVIA LITHUANIA COOPERATION PROJECT "Up-to-date Information Systems in Urban Regeneration"), 2020. gada 20. novembrī tiešsaistē.

4. Treija, S., Bratuškins, U., Koroḷova, A., Lektauers, A. Identifying Digital Tools for Social Sustainability in Urban Regeneration in Riga. Riga Technical University 61st Internetional Scientific Conference Architecture and Urban Planning / RTU 61. Starptautiskā zinātniskā konference sekcija Arhitektūra and pilsētplānošana, 2020. gada 16. oktobrī tiešsaiste.

5. Korolova, A., Treija, S. Infill Development and Its Impact on The Public Open Space In Large Housing Estates: Case of Riga. AESOP Annual Congress 2019 : Planning for Transition, Itālija, Venēcija, 2019. gada 9.-13. jūlijā.

6. Korolova, A. Investigation of Residents' Satisfaction with the Outdoors of Large Housing Estates. $60^{\text {th }}$ Riga Technical University International scientific conference section Architecture and urban planning / RTU 60. Starptautiskā zinātniskā konference sekcija Arhitektūra and pilsētplānošana, Latvija, Rīga, 2019. gada 17. oktobrī.

7. Korolova, A. Relationships Between Urban Public Space Use and Residential Satisfaction In Large-Scale Housing Estates. 59 $9^{\text {th }}$ Riga Technical University International scientific conference section Architecture and urban planning / RTU 59. starptautiskā zinātniskā konference sekcija Arhitektūra and pilsētplānošana, Latvija, Rīga, 2018. gada 11. oktobrī.

8. Treija, S., Koroḷova, A., Āboliṇa, K. Pagalmu dārzkopības attīstības iespējas un izaicinājumi Rīgas lielmēroga dzìvojamo rajonu kontekstā. LU 76.zinātniskā conference, Zemes un vides zinātnu nozares sekcija, Apakšsekcija "Vietu plānošana un attīstība". Latvija, Riga, 2018. gada 1. februārī.

9. Treija, S., Koroḷova, A., Latkowska, M. Effectiveness of CPTED Principles: The Case of Urban Allotment Gardens. 57 ${ }^{\text {th }}$ Riga Technical University International scientific conference section Architecture and urban planning / RTU 57. Starptautiskā zinātniskā konference sekcija Arhitektūra and pilsētplānošana, Latvija, Rīga, 2016. gada 14. oktobrī.

10. Korolova, A. The Meaning of Urban Gardening in Relation to Local Peculiarities. COST Action TU 1201 conference Urban Allotment Gardens in European Cities Future, Challenges and Lessons Learned Thessaloniki Joint MC and WG Meeting, Grieksija, Saloniki, 2016. gada 16.-19. martā. 
11. Koroḷova, A. Urbānās dārzkopības nozīme pilsētvides reǵenerācijā. LU 76.zinātniskā conference, Zemes un vides zinātņu nozares sekcija, Apakšsekcija "Vietu plānošana un attīstība", Latvija, Rīga, 2016. gada februārī.

\section{Dalība starptautiskās doktorantu konferencēs}

1. Korolova, A., Implementation of Temporary Urbanism for Revitalisation of Residential Outdoor Spaces. CARE Conference for Artistic and Architectural (Doctoral) research, Slovēnija, Lubḷana, 2017. gada septembrī. pp. 169-177. http://www.fa.uni-lj.si/filelib/1_ strani_predmetov/tadeja_zupancic/projekti/2018-03-15-ca2re-bookpass.pdf.

2. Korolova, A. Strategic Goals for Physical Activity Reflected in Urban Planning Documents. Proceedings of the CARE Conference for Artistic and Architectural (Doctoral) research, KU Leuven, Faculty of Architecture, Belǵgija, G̦ente, 2017. gada 7.-9. aprīlī. pp. 241-248.

https://arch.kuleuven.be/english/research1/publications/ proceedings-ca2re-2017.pdf.

3. Korolova, A. Temporary Urbanism Solutions for Urban Regeneration. $\mathrm{PhD}$ Workshop in terms of Sustainable Built Environment SBE16 Hamburg Conference, Vācija, Hamburga, 2016. gada 11. martā. http:// www.zebau.de/projekte/sbe16-hamburg.

4. Korolova, A. Regeneration of the Outdoor Environment in Large-Scale Housing Estates. Second Baltic State Seminar for Doctoral Research, Latvija, Rīga, 2018. gada 12. oktobrī.

5. Korolova, A. Relationships between Urban Public Space Layout and Residential Satisfaction in Large-Scale Housing Estates. First Baltic State Seminar for Doctoral Research, Latvija, Rīga, 2017. gada 12. oktobrī.

\section{Raksti profesionālās ievirzes žurnālos}

1. Treija, S., Korolova, A. Mūsdienu urbānā dārzkopība un tās daudzveidīgās izpausmes. Latvijas Arhitektūra, 2018., maijs-jūnijs (ieguvis žurnāla Latvijas arhitektūra atzinības rakstu kā gada labākā zinātniskā publikācija). 


\section{LIELMĒROGA DZİVOJAMO RAJONU ĀRTELPAS ATTĪITTİBA EIROPĀ}

Pirmās nodạ̦as pamatā ir lielmēroga dzīvojamo rajonu ārtelpas genēzes pārskats. Tajā apzināti faktori, kas ietekmēja lielmēroga dzīvojamo rajonu rašanos Eiropas valstīs. Idejas par daudzstāvu dzīvojamām ēkām, kas ir plaši izvietotas teritorijā un starp kurām ir zaḷās apstādījumu joslas, parādījās jau 20. gadsimta 30. gados [17], [197]. Sākotnējās lielmēroga dzīvojamo rajonu ārtelpas koncepcijas pamatā bija no automašīnām brīva vide un daudzveidīgo funkciju izkārtojums pastaigas pieejamā attālumā [38].

Neskatoties uz to, ka lielmēroga dzīvojamie rajoni tika plaši būvēti visā Eiropā un tiem piemīt daudzas līdzīgas pazìmes formās un funkcijās, vērojama arī nozīmīga veidošanās un attīstības trajektoriju dažādība [19], [20], [49]. Tomēr vairāku Eiropas pilsētu lielmēroga dzīvojamo rajonu analīze parādīja, ka publiskās ārtelpas telpiskā organizācija bija līdzīga Ziemel̦eiropas un Baltijas valstīs. Lietojot vienāda tipa telpiskās organizācijas principus, bet veidojot cita mēroga apbūvi un ārtelpu, tika panākts atšksirīgs rezultāts. Baltijas valstu arhitekti iedvesmojās no Ziemel̦valstu lielmēroga dzīvojamo rajonu paraugiem, tomēr pārṇemtās idejas ne vienmēr bija iespēja realizēt. Analizētie piemēri pierādīja, ka liela nozīme ir arī reljefam, augsnes kvalitātei un esošiem dabas elementiem.

Lielmēroga dzīvojamo rajonu attīstību lielā mērā ietekmēja konteksts, būvniecības periods un mērogs, izvietojums pilsētā, apsaimniekošana, iedzīvotāju struktūra, stigmatizācija, vietējā ekonomika un citi faktori.

\section{1. Ārtelpas ǵenēze un raksturs lielmēroga dzīvojamos rajonos}

Pirmās nodal̦as pirmajā apakšnodal̦ā apkopota informācija par lielmēroga dzīvojamo rajonu ārtelpas attīstības tendencēm, noteikti telpiskās organizācijas veidi. Piemēru izpēte parādīja, ka, neraugoties uz atšķirīgo politisko situāciju un vietējām īpatnībām arhitektu un pašvaldību lomās, dažādām Eiropas valstīm bija zināmas līdzības lielmēroga dzīvojamo rajonu plānošanas pieejā [19], 
[20], [49]. Tika noteikti vairāki telpiskās organizācijas veidi. Turklāt bieži lielmēroga dzīvojamos rajonos tika apvienoti dažādi telpiskās organizācijas principi. Piemēram, vienā rajonā var tikt apvienots "paralēli izkārtoto ēku" (parallell blades), "pusatvērtas telpas" (semiclosed structures) un "neregulāra tipa telpas" (irregular open space) princips. Neskatoties uz rajonu līdzībām telpiskajā organizācijā, mēroga un blīvuma aspektos konstatējama izteikta daudzveidība, kas nozīmīgi ietekmē ārtelpas izmantošanu.

\section{2. Ārtelpas loma iedzīvotāju vajadzību apzināšanā}

Pirmās nodaḷas otrajā apakšnodaḷā apkopota informācija par lielmēroga dzīvojamo rajonu ārtelpas lomu iedzīvotāju vēlmju un vajadzību apzināšanā. Zạ̦ā ārtelpa ir viena no lielmēroga dzīvojamo rajonu raksturīgajām iezīmēm. Kā rāda vairāki pētījumi, tai ir arī liela nozīme iedzīvotāju fiziskās un psihoemocionālās veselības nodrošināšanā. RESTATE projektā veiktās lielmēroga dzīvojamo rajonu iedzīvotāju aptaujas rezultāti pierādīja, ka zạ̦ā ārtelpa tiek uzskatìta par pozitīvāko rajona īpašību [49]. Tomēr liela nozīme ir ne tikai zal̦ās ārtelpas klātbūtnei, bet arī tās kvalitātei, ko veido tās apsaimniekošana, tīrība, kārtība un citi aspekti.

Lielmēroga dzīvojamo rajonu ārtelpas būtiska nozīme ir arī sociālai telpai [64, 47]. Tomēr daudzi pētījumi pierādīja, ka, sekojot funkcionālisma dizaina principiem, neizdevās izveidot aicinošas publiskās ārtelpas, kas veicina iedzīvotājus tās izmantot [49, 132], [73], [109]. Neskaidra telpiskā organizācija neḷauj attīstīt vietas piederības sajūtu, iedzīvotāji nejūtas atbildīgi par vidi, un tas savukārt veicina dažāda veida sociālās problēmas. Publiskās, kā arī publiskās un privātās ārtelpas organizācija l̦autu veicināt iedzīvotāju piederības sajūtu un paaugstinātu viņu atbildības sajūtu.

\subsection{Lielmēroga dzìvojamo rajonu ārtelpas loma pilsētu zaḷās infrastruktūras sistēmā}

Pirmās nodaḷas trešajā apakšnodạ̣ā analizēta lielmēroga dzīvojamo rajonu ārtelpas loma pilsētu zaḷās infrastruktūras kontekstā. Lielmēroga dzīvojamo rajonu būtiska sastāvdaḷa ir plašās apzalı umotas teritorijas, tādējādi arī 21. gadsimta trešajā desmitgadē tiem 


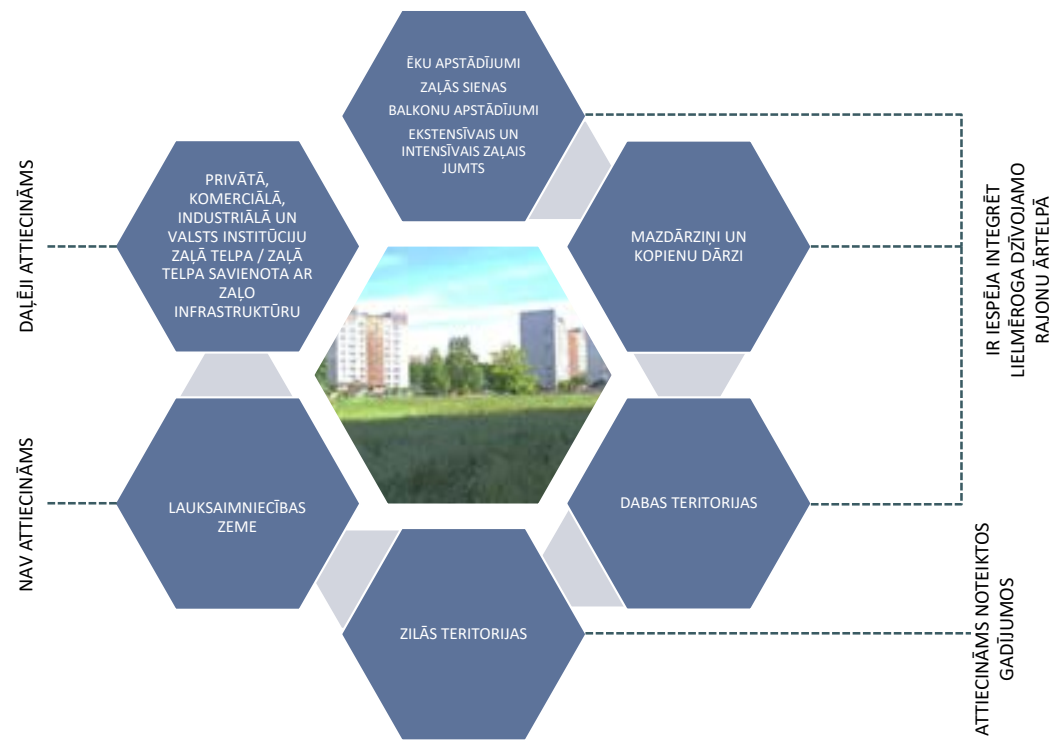

1. att. Pilsētas zaḷās infrastruktūras elementi un to integrācijas potenciāls lielmēroga dzīvojamo rajonu ārtelpā. [Autores veidota diagramma, izmantojot Green Surge projektā definētās pilsētas zaḷās infrastruktūras tipologiijas [150]].

ir potenciāls veidot dalı no pilsētas zaḷās infrastruktūras (1. att.) [209], [210], [225], [247]. Tomēr izaicinājums ir ārtelpas nenoteiktā izmantošana vai funkcionālās daudzveidības trūkums. Citu Eiropas pilsētu piemēri rāda, ka lielmēroga dzīvojamo rajonu ārtelpa var nodrošināt daudzveidīgus ekosistēmas pakalpojumus. Daži risinājumi, piemēram, ilgtspējīgas lietus ūdens apsaimniekošanas ieviešana, lietus dārzi, ir ilgtermin,a procesi, kas prasa ievērojamu finansējumu. Tomēr pastāv arī neliela mēroga īstermiṇā īstenojamas transformācijas, piemēram, kopienas dārzu integrācija (piemēri Malmē, Zalcburgā, Tallinā un citi) [237].

Pēdējās desmitgades laikā pieaug interese par apritīguma pieeju arhitektūrā un pilsētplānošanā. Tiek meklētas idejas dabā balstītiem risinājumiem ar integrētiem apritīguma principiem. Līdz ar to ar dabā balstīto risinājumu ieviešanu lielmēroga dzīvojamo rajonu ārtelpā tiek atbalstīti daudzveidīgi ekosistēmu pakalpojumi. 


\section{LIELMĒROGA DZĪVOJAMO RAJONU DZİVOJAMĀS VIDES KVALITĀTE UN ĀRTELPAS TRANSFORMĀCIJAS}

Otrajā nodal̦ā apkopota un analizēta informācija par lielmēroga dzīvojamo rajonu ārtelpas transformāciju veidiem un transformācijas ietekmējošiem faktoriem. Šìm transformācijām mēdz būt gan pozitīva, gan negatīva ietekme uz dzìvojamās vides kvalitāti. Līdz ar to transformāciju ietekmes uz dzīvojamās vides kvalitāti apzināšanai ir būtiska loma sabalansētā lielmēroga dzīvojamo rajonu ārtelpu attīstībā.

\subsection{Lielmēroga dzivojamo rajonu ārtelpas transformācijas Eiropā}

Otrās nodaḷas pirmajā apakšnodal̦ā apkopota informācija par lielmēroga dzīvojamo rajonu ārtelpas transformāciju kontekstu un transformāciju veidiem. Zemes reforma un īpašuma denacionalizācija 20. gadsimta 90. gados [257] ir radījusi pašreizējo sarežgiìto situāciju, kad ārtelpa lielmēroga dzīvojamos rajonos ir sadrumstalota, tai ir daudzi īpašnieki, bieži zeme pieder privātpersonām, kurām nav motivācijas ārtelpas attīstībā. Latvijā pēc neatkarības atjaunošanas 20. gadsimta 90. gados gados iesākās vairākas izmaiņas: zemes reforma, īpašumu denacionalizācija, pieauga ārtelpas apsaimniekošanas izmaksas, vērojams privāto investoru spiediens. Pakāpeniski attīstījās demokrātiskāka pārvalde, un šobrīd iedzīvotāju līdzdalība pilsētplānošanas procesos ieṇem aizvien lielāku lomu [218], [224], [226].

Izšksir ārēji vadītas ārtelpas transformācijas un transformācijas ar pašorganizēto iesaisti. Transformāciju veidi iedalīti četrās lielās grupās: 1) iedzīvotāju iniciētas (bottom-up - angḷ u val.) transformācijas; 2) privāto attīstītāju veicinātas transformācijas; 3) pašvaldības veicinātas transformācijas; 4) līdzdalīgās budžetēšanas rezultātā radušās transformācijas.

Viena no pētniecības metodēm ietvēra kopienas dārza eksperimentu Juglas lielmēroga dzìvojamā rajonā. Eksperimenta mērķis bija pārbaudīt tāda iedzīvotāju iniciēta transformācijas procesa 
saskaṇošanas procedūru, kas paredz ārtelpas zal̦ās teritorijas saglabāšanu un l̦auj dažādot ekosistēmas pakalpojumus, kā arī noteikt iespējas un škēèšlus oficiālās atl̦aujas saṇemšanai. Viens no nozīmīgiem eksperimenta uzdevumiem bija arī novērtēt iedzīvotāju ieinteresētību, gatavību iesaistīties aktivitātē un tālākā apsaimniekošanā.

Eksperimenta gaitā tika veiktas aptaujas, un iedzīvotāji tika iesaistīti mobilā dārza iekārtošanā. Šì eksperimenta rezultātā tika atklāta liela bērnu interese un vēlme darboties dārzā, tajā pat laikā rezultāti pierādīja arī to, ka pastāvīgā dārza ierīkošanai nepieciešams atbalsts un vēlme uzturēt dārzu vietējo pieaugušo iedzīvotāju vidū. Oficiālā saskan,ošana kḷuva par lielāko šķērsli kopienas dārza projekta īstenošanā un rezultējās neformālā "mobilā dārza" aktivitātē 2017. gada jūnijā. Tika pierādīts, ka oficiālās atḷaujas saṇemšanas process šāda tipa transformācijai ir ilgs, sarežgìts un necaurspīdīgs, līdz ar to rada vairāk škēršl̦u, nevis atbalstu ekosistēmas pakalpojumu daudzveidošanai.

Daudzās pasaules valstīs pētnieki ir atzinuši sabiedrības iesaistīšanās izškirīgo lomu un potenciālu, ko piedāvā līdzdalīgās budžetēšanas rīki [13], [18], [34]. Rīgā līdzdalīgā budžetēšana pilsētas reǵenerācijai ir salīdzinoši jauna pieeja, ko var skaidrot arī ar ievērojami vēlāku iedzīvotāju līdzdalības aktivizāciju un vēlāko pāreju

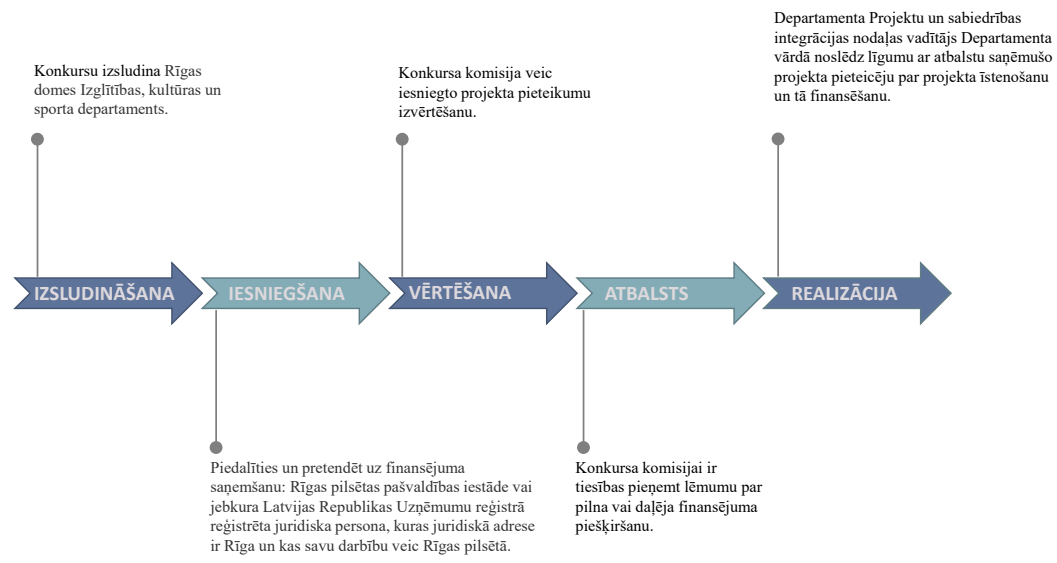

2. att. „Apkaimju iniciatīvas līdzdalības un piederības veicināšanai” projektu pieteikšanas un vērtēšanas process. 
uz demokrātiskāku pārvaldi Baltijas valstīs, salīdzinot ar Rietumeiropas pilsētām. Pirmā līdzdalīgās budžetēšanas programma Rīgā "Apkaimju iniciatīvas līdzdalības un piederības veicināšanai" tika organizēta 2016. gadā [228]. Dažādām līdzdalīgās budžetēšanas programmām ir atšksirīgi projektu iesniegšanas noteikumi, novērtēšanas un apstiprinājuma process, kā arī atškirīgs iedzīvotāju līdzdalības līmenis (2. att.).

Sākot no 2019. gada, Rīgā tiek organizēts Rīgas pilsētas līdzdalības budžeta projektu ideju īstenošanas konkurss [218], [226]. Salīdzinot ar konkursiem, kas tiek izsludināti "Apkaimju iniciatìvas līdzdalības un piederības veicināšanai" ietvaros, Rīgas pilsētas līdzdalības budžeta projektu ideju îstenošanas konkursā ir pieejams lielāks budžets, kā arī ir lielāka iedzīvotāju iesaiste, nodrošinot ne tikai līdzdalību projektu ideju iesniegšanas posmā, bet arī balsošanas posmā.

Līdzdalīgās budžetēšanas rezultātā radīto aktivitāšu un reǵenerācijas projektu izplatība Rīgā rāda to fragmentāro raksturu, kas rezultējas ar dažu apkaimju intensīvāku pilsētvides uzlabošanu, savukārt vairumā apkaimju vērojams vietējo nevalstisko organizāciju trūkums vai arī to pasīva pozīcija. Piemēram, Čiekurkalnā, Sarkandaugavā un Maskavas forštatē ir aktīvāki nevalstisko organizāciju pārstāvji, līdz ar to te pilsētu atjaunošanas aktivitātes notiek biežāk, procesi notiek ātrāk un ar plašāku sabiedrības līdzdalību. Savukārt citās apkaimēs četru gadu laikā (no 2016. līdz 2019. gadam) ir īstenots tikai viens vai nav îstenots neviens projekts.

\subsection{Dzīvojamās vides kvalitātes koncepts un vērtēšanas metodes}

Otrās nodaḷas otrajā apakšnodạ̣ā apzināta ar pilsētas dzīves kvalitāti saistīto jēdzienu daudzveidība. Dzīves kvalitāte, pilsētas dzīves kvalitāte, vides kvalitāte ir plaši jēdzieni, kas bieži ietver arī dzīvojamo rajonu ārtelpas raksturojošus kritērijus [38], [66], [67], [68], [74], [80], [82]. Taču rīki, kas tiek izmantoti vispārējai dzīves kvalitātes vai dzīvojamās vides kvalitātes vērtēšanai, iekḷauj l̦oti plašu kritēriju loku. Dzīvojamās vides kvalitātes jēdziens kopsakarībā ar vietas kvalitātes koncepciju izmantots, lai apzinātu lielmēroga dzīvojamo rajonu ārtelpas kvalitātei vērtējumam 
izmantojamo vērtēšanas rīku daudzveidību. Jēdzienu un pieeju daudzveidība ir radījusi daudzveidīgas dzìvojamās vides kvalitātes vērtēšanas metodes. Tās var iedalīt trīs lielās grupās: 1) iedzīvotāju aptaujas vai intervijas, kas sniedz subjektīvu vides uztveres pārskatu; 2) administratīvie dati un geogrāfiskās informācijas sistēmas dati; 3) tiešs novērojums un pilsētvides apsekošana, ko veic ārēji vērtētāji (ieskaitot audita instrumentu izmantošanu).

\section{3. Ārtelpas transformāciju ietekmes uz dzīvojamās vides kvalitāti vērtēšana}

Otrās nodal̦as trešā apakšnodaḷa veltīta esošo pilsētvides kvalitātes vērtēšanas rīku izpētei un analīzei un dzīvojamās vides kvalitātes vērtēšanas model̦a izstrādei. Izmantojot atslēgas vārdus, tika sistemātiski izpētīti zinātniskie raksti Science direct un Scopus datubāzēs, kas publicēti no 2000. līdz 2019. gadam, izmantojot PRISMA metodologiju (kopā 1183 raksti). Analizējot dažādu pilsētvides kvalitātes vērtēšanas rīku kopsakarības, tika identificēti kopīgie un visbiežāk sastopami vērtēšanas faktori. Nākamajā posmā tika iekḷauta vietas kvalitātes pazīmju analīze, kas iegūta no Metjū Karmona pētījuma un ietver 271 empīrisko pētījumu analīzi [195]. Modelī tika iekḷautas Džona Caisela (John Zeisel) definētās cilvēku vajadzības, kā arī traucējumu jeb stresu izraisoši indikatori, ko nodefinējis Maikls Pacione (Michael Pacione) [43]. Pētījuma rezultātā apkopota informācija par dzīvojamās vides kvalitātes novērtēšanas metodēm. Apkopota un analizēta informācija par funkciju sasniedzamības koncepciju, funkcijām un ārtelpas īpašībām, kas nepieciešamas mājas tiešā tuvumā un 10 minūšu gājiena attālumā, un dati, kas tika iegūti aptaujā par iedzīvotāju apmierinātību ar ārtelpas kvalitāti lielmēroga dzīvojamos rajonos un transformāciju ietekmi uz tās. Visu šo aspektu un dažādu pilsētvides kvalitāti noteicošo indikatoru integrācija vienā pieejā rezultējās ar dzīvojamās vides kvalitātes vērtēšanas konceptuālo modeli (3. att.).

Izstrādāto pieeju var izmantot gan jau notikušo transformāciju ietekmes novērtēšanai, gan nākotnes transformāciju iespējamo seku analīzei un alternatīvu scenāriju meklēšanai (4. att.). Apsverot gan dažādu iedzìvotāju grupu vajadzības, gan esošo situāciju, ir iespēja izvēlēties gan transformāciju veidu, gan izvietojumu, kas veicinās 


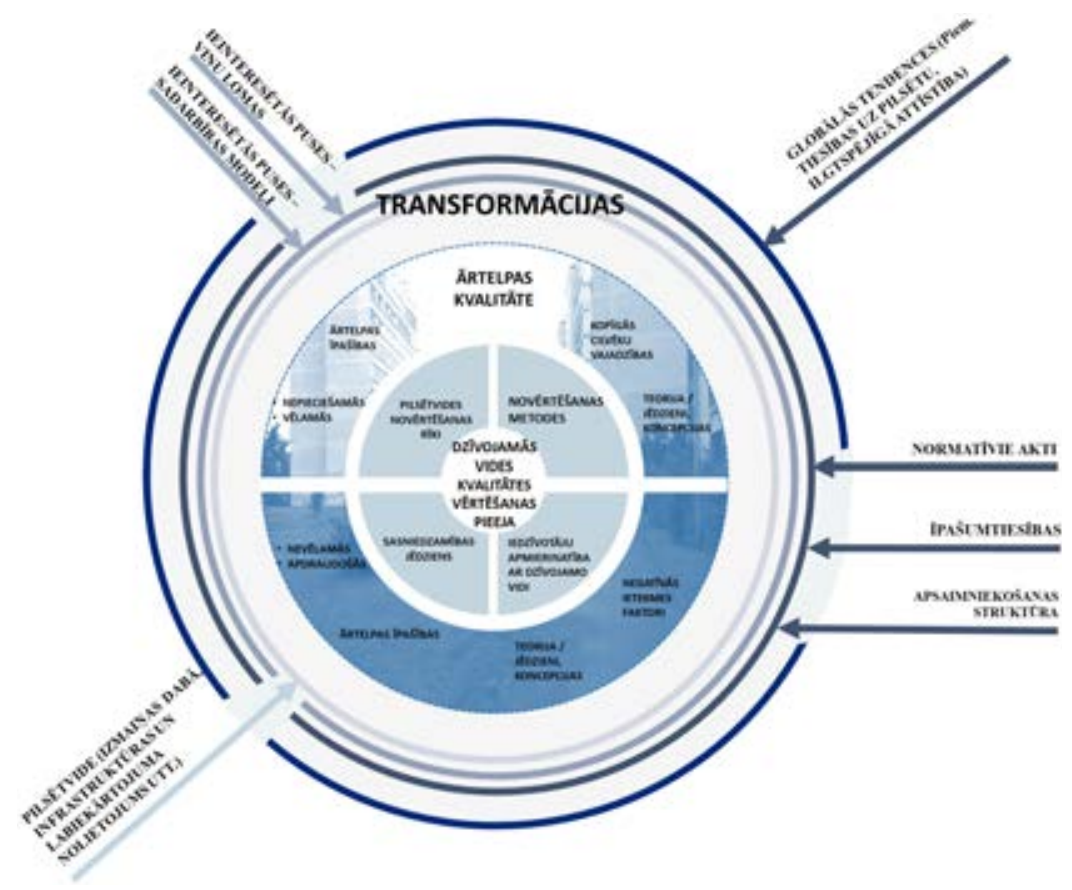

3. att. Dzīvojamās vides kvalitātes novērtēšanas pieeja konceptuālais modelis.

dzīvojamās vides kvalitātes uzlabošanos. Kategorijas, kas apraksta dažādas cilvēku vajadzības un stresa faktorus, ir saistītas ar vēlamajiem rezultātiem un tiem rezultātiem, no kuriem jāizvairās. Transformāciju plānošana un to ietekmes vērtējums visa lielmēroga dzìvojamā rajona ārtelpās kopumā ir nopietns priekšnoteikums kvalitatīvās dzīvojamās vides radīšanai.

Piemēram, jaunās apbūves integrācijai lielmēroga dzīvojamo rajonu teritorijās var būt gan negatīva, gan pozitīva ietekme uz dzīvojamās vides kvalitāti. Pamatojoties uz Maikla Paciones definētājiem stresu izraisošiem indikatoriem [43], jaunā apbūve, kas tiek attīstīta lielmēroga dzìvojamo rajonu ārtelpā un transformē publiski pieejamu ārtelpu par iežogoto teritoriju ar norobežoto piekḷuvi, darbojas kā stresu izraisošais indikators. Savukārt jaunā 


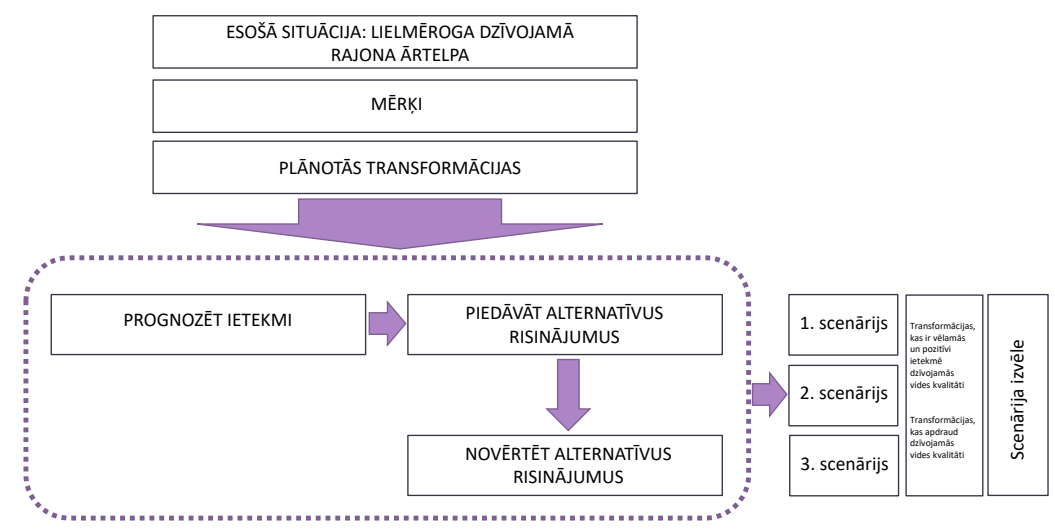

4. att. Iespējamo nākotnes ārtelpas transformāciju ietekmes uz dzīvojamās vides kvalitāti vērtējums - konceptuālais modelis.

apbūve, kas attīstīta, ievērojot ēku izvietojumu attiecībā pret esošo apbūvi, jaunbūves augstumu un citus faktorus un kas piedāvā koplietošanas rekreācijas iespējas, pozitīvi ietekmē dzīvojamās vides kvalitāti. 


\section{RĪGAS LIELMĒROGA DZĪVOJAMO RAJONU ĀRTELPAS TRANSFORMĀCIJU IETEKME UZ DZĪVOJAMĀS VIDES KVALITĀTI}

Trešā nodaḷā apkopoti un analizēti Rīgas lielmēroga dzīvojamo rajonu ārtelpas novērtēšanas rezultāti. Lai papildinātu kvantitatīvus datus, kas iegūti ārtelpu apsekošanas rezultātā, kā arī veicot aktivitāšu novērojumus dabā, izstrādāta aptauja. Iedzīvotāju aptaujā gūti rezultāti atbalsta apsekošanas rezultātā gūtās atziṇas.

\subsection{Lielmēroga dzīvojamo rajonu ārtelpas rakstura iezīmes}

Trešās nodaḷas pirmajā apakšnodal̦ā izveidota Rīgas lielmēroga dzīvojamo rajonu publiskās ārtelpas klasifikācija. Par pamatu izmantoti Kristofera Aleksanda (Christopher Alexander) "A Pattern language" grāmatā piedāvāti pilsētvides raksturi, kā arī Nikos Salingaros (Nikos Salingaros), Pjetro Paliardini (Pietro Pagliardini), Jana Gēla (Jan Gehl), Kamillo Zite (Camillo Sitte) un citu pētnieku atziṇas par veiksmīgas publiskās ārtelpas raksturīgām pazīmēm [1], [14], [15], [53], [163]. Ārtelpas telpiskās organizācijas analīzes rezultātā telpiskās organizācijas tipi iedalīti trīs kategorijās: pozitīvā telpa; cel̦a rakstura telpa; nenodefinētā telpa. Pamatojoties uz novērojumiem Juglas lielmēroga dzīvojamā rajona ārtelpā, noteiktas kopsakarības starp publiskās ārtelpas telpisko organizāciju, ārtelpas labiekārtojumu un izmantošanas veidiem.

\section{2. Ārtelpas kvalitātes transformācijas lielmēroga dzivojamos rajonos}

Trešās nodal̦as otrā apakšnodal̦a veltīta pilsētvides apsekošanas rezultātiem, kas parāda transformācijas šādos Rīgas lielmēroga dzīvojamos rajonos: Āgenskalna priedes, Sarkandaugava, Jugla, Ķengarags, Imanta, Purvciems, Bolderāja, Ilıguciems, Vecmīlgrāvis, Mežciems, Pḷavnieki, Zolitūde un Ziepniekkalns. Ārtelpa lielmēroga dzīvojamos rajonos apsekota, izmantojot dzīvojamās vides kvalitātes vērtēšanas pieeju. Apsekojuma rezultātā konstatēti transformāciju veidi un to ietekme uz dzīvojamās vides kvalitāti. 
Visu apsekoto lielmēroga dzīvojamo rajonu ārtelpā vērojama iedzīvotāju iniciatīva vietas veidošanā. Iedzīvotāju veicinātās neformālās transformācijas vērstas gan uz jaunu apstādījumu veidošanu, gan uz ārtelpas detaḷiekārtu izveidi. Tas parāda iedzīvotāju piederības sajūtu un rūpes par apkārt esošo vidi. Pēc drošās vides dizaina principiem (Crime prevention through environmental design) [41] šāda tipa aktivitātes parāda, ka par teritoriju kāds rūpējas un līdz ar to palīdz novērst antisociālo uzvedību.

Lielmēroga dzīvojamo rajonu ārtelpā visizplatītākās problēmas, kas pazemina dzīvojamās vides kvalitāti, ir neapmierinošs vides pieejamības līmenis, privātuma trūkums jeb nespēja regulēt sociālo kontaktu daudzumu, kā arī vienveidīgas rekreācijas iespējas. Brīžiem transformācijas, kas tiešā mērā ietekmē minētos aspektus un var kalpot dzīvojamās vides kvalitātes paaugstināšanai, rezultējas ar risinājumiem, kas kvalitāti pazemina.

Vienāda tipa bērnu rotaḷu un sporta laukumi pakāpeniski tiek integrēti lielākajā daḷā lielmēroga dzīvojamo rajonu ārtelpā. Tomēr standartizēti risinājumi nel̦auj veidot vietas identitāti. Gan citu pilsētu pieredze, gan Rīgā pēdējo gadu laikā realizētie iedzīvotāju līdzdalības projekti liecina, ka iedzīvotāju līdzdalība plānošanas un vides veidošanas procesos palīdz izcelt vietas atpazīstamību, kā arī veicina apkaimes piederības sajūtas stiprināšanos.

Zemes īpašumtiesības un lielmēroga dzìvojamo rajonu ārtelpas sadrumstalotais zemes vienību dalījums ir viens no noteicošajiem faktoriem, kas liedz sabalansētu ārtelpas attīstību. Kopīga lēmuma kopīpašumu jautājumos rezultāti šobrīd ir vērojami autostāvvietu reglamentējošo zīmju izvietošanas gadījumos. Savukārt labiekārtojums atpūtai bieži tiek veidots neformālo aktivitāšu rezultātā.

\subsection{Kopsakarības starp iedzīvotāju viedokli un ārtelpas transformācijām}

Iedzīvotāju viedoklim ir svarīga loma dzīvojamās vides kvalitātes vērtēšanā, tāpēc pētījumā tika izstrādāta iedzīvotāju aptauja ar mērḳi apzināt Rīgas lielmēroga dzīvojamo rajonu iedzīvotāju ārtelpas izmantošanas paradumus, attieksmi pret transformācijām, kas jau notikušas, un iespējamām transformācijām ārtelpā nākotnē. 
Aptaujā piedalījās 240 respondentu, kas dzīvo Juglas, Purvciema, Imantas un Ziepniekkalna lielmēroga dzīvojamos rajonos. Lielākā daḷa respondentu dzīvo šajos lielmēroga dzīvojamos rajonos vairāk nekā piecus gadus.

Aptauju veido 24 jautājumi. 12 jautājumi ir par lielmēroga dzīvojamā rajona publiskās ārtelpas kvalitāti un transformācijām. Vēl 12 jautājumi vērsti uz informāciju par to, cik ilgi un kurā lielmēroga dzīvojamā rajona daḷā respondents dzīvo, par zemes īpašumtiesībām utt.

Rezultāti parādīja, ka vairums respondentu (75 \% Purvciemā, 64 \% Imantā, 77 \% Juglā un 75 \% Ziepniekkalnā) drīzāk nav apmierināti vai ir pilnībā neapmierināti ar ārtelpas kvalitāti savā lielmēroga dzīvojamā rajonā. Viens no biežāk minētajiem ārtelpas izmantošanas veidiem ir automašinnas novietošana. Šim izmantošanas veidam seko pastaigas, pastaigas ar suni un pastaigas ar bērniem un mazbērniem. Zemo ārtelpas izmantošanas līmeni veicina neapmierinātība ar telpisko organizāciju, rekreācijas iespēju un daudzveidības trūkums, kā arī neapmierinošs apsaimniekošanas līmenis. Bieži respondenti izvēlas brīvo laiku pavadīt dabas teritorijās - mežā, parkā, pie ezera vai pilsētas centrā.

Vēlamākās transformācijas, ko minēja vairāk nekā 90 \% respondentu, ir jauni apstādījumi, koki un puķu dobes, vides pieejamības nodrošināšana un atkritumu urnas suṇu ekskrementiem. Jaunās dzīvojamās apbūves attīstība vērojama gandrīz visos lielmēroga dzīvojamos rajonos Rīgā. Respondentiem tika uzdots jautājums par to, kādi aspekti ḷautu akceptēt jaunās apbūves izveidi vai arī - nebūtu piel̦aujami, būvējot jaunas dzīvojamās ēkas lielmērogā dzīvojamos rajonos. Piel̦aujot jaunas apbūves veidošanu, respondenti vēlētos tās tuvumā redzēt jaunus apstādījumus, koplietošanas atpūtas iespējas un bērnu rotalı laukumus, kā arī autostāvvietas. Respondentiem kopumā ir negatīva attieksme pret apbūvi, kas ir augstāka par pieciem stāviem, kā arī pret nožogotām teritorijām un privātmāju apbūvi lielmēroga dzīvojamo rajonu teritorijās. 


\section{SECINĀJUMI}

1. Līdzības ārtelpas telpiskajā organizācijā lielmēroga dzīvojamos rajonos Baltijā un Ziemel̦eiropā rada priekšnoteikumus līdzīgu risinājumu meklējumos dzīvojamās vides kvalitātes uzlabošanai. Risinājumu veiksmīgai adaptācijai būtisks ir ne tikai ēku savstarpējais izvietojums un ārtelpas mērogs, bet arī apbūves mērogs, apstādījumu daudzums un kvalitāte, augsnes īpatnības un citi faktori.

2. Lielmēroga dzīvojamo rajonu iedzīvotāji pārstāv atšksirīgas grupas ar dažādām atpūtas un socializācijas vajadzībām un vēlmēm. Dažkārt šìs vajadzības ir pat konfliktējošas. Atpūtas iespēju plānošana, apsverot visa lielmēroga dzīvojamā rajona attīstību, l̦auj radīt savstarpēji savienotu ārtelpas pakalpojumu struktūru, nodrošinot pakalpojumu savietotību un sasniedzamību. Tādā veidā tiek nodrošināta dažādu iedzīvotāju grupu apmierinātība ar dzīvojamās vides kvalitāti.

3. Lielmēroga dzīvojamo rajonu būtiska sastāvdaḷa ir plašās apzaḷumotās teritorijas, tādējādi arī 21. gadsimta trešajā desmitgadē tiem ir potenciāls veidot daḷu no pilsētas zaḷās infrastruktūras. Piemēri citās Eiropas pilsētās demonstrē iespēju attīstīt bagātīgu daudzfunkcionālu zaḷo vidi, kas nodrošina dažādus ekosistēmas pakalpojumus, attīstot gan īstermiṇa, gan ilgtermiṇa projektus. Daži risinājumi, piemēram, ilgtspējīgas pilsētas ūdens drenāžas sistēmas, tiek realizēti ar lielām investīcijām vairāku gadu laikā, savukārt citi, piemēram, kopienu dārzkopības iniciatīvas, parādās kā ātri un pagaidu risinājumi, kur izveides laiks mainās atkarībā no dažādiem faktoriem, tādiem kā zemes īpašumtiesības, dizaina sarežgîitība un vietējās sabiedrības atbalsts.

4. Transformācijas, kas notiek lielmēroga dzīvojamo rajonu ārtelpā, atšksiras pēc veida un mēroga, kā arī pēc virzītājspēka. Lai gan šiem dažādajiem virzịtājspēkiem ir atšksirīgi mērksi, gadījumos, kad dalībniekiem tiek skaidri definētas lomas un tiek nodrošināta kvalitatīva procesa pārvaldība, tiek realizētas augstas kvalitātes transformācijas, kas atbilst visu iesaistīto dalībnieku vajadzībām. 
5. Daudzviet Eiropas pilsētās tiek izmantotas vadlīnijas un labās prakses rokasgrāmatas, lai atbalstītu gan ekspertus, gan citus iesaistītos dalībniekus lēmumu pien,emšanā un izvairītos no raksturīgām problēmām. Zināšanu apmaiṇai starp profesionāḷu un akadēmisko vidi, kā arī zināšanu pārnesei (pašvaldību pārstāvjiem, iedzīvotājiem), ir izšksiroša nozīme, lai nepiel̦autu kḷūdu atkārtošanos un veicinātu labās prakses pārṇemšanu.

6. Pilsētvides kvalitātes novērtēšanai ir izstrādāti atšķirīgi rīki ar daudzveidīgiem novērtēšanas kritērijiem. Vairums no tiem ietver plašu vērtēšanas kritēriju kopu un rezultātā novērtē ne tikai ārtelpas kvalitātes, bet arī transporta infrastruktūras, pakalpojumu pieejamības un citus aspektus. Vairāki rīki paredzēti neliela mēroga teritoriju un atsevišķu iedzīvotāju grupu vajadzību apzināšanai un dzīvojamās vides kvalitātes novērtēšanai. Lai šos rīkus izmantotu transformāciju ietekmes novērtēšanai lielmēroga dzīvojamo rajonu ārtelpas kvalitātes kontekstā, ir nepieciešama rīku adaptācija lokālai situācijai un papildinājumi ar novērojumiem uz vietas.

7. Lielmēroga dzīvojamo rajonu dzīvojamās vides kvalitātes novērtēšanas pieeja ietver adaptēto ārtelpas kvalitātes novērtēšanas rīku, ieteikumus par ārtelpas funkciju sasniedzamību, vērtēšanas metožu apkopojumu un studijas par iedzìvotāju apmierinātību ar dzīvojamās vides kvalitāti. Pieeju var izmantot gan jau notikušo transformāciju ietekmes novērtēšanai, gan nākotnes transformāciju iespējamo seku analīzei un alternatīvu scenāriju meklēšanai. Kategorijas, kas apraksta dažādas cilvēku vajadzības un stresa faktorus, ir saistītas ar vēlamajiem rezultātiem un tiem rezultātiem, no kuriem jāizvairās. Transformāciju plānošana un vērtējums visa lielmēroga dzīvojamā rajona ārtelpās kopumā ir nopietns priekšnoteikums kvalitatīvas dzīvojamās vides radīšanai.

8. Atškkirīgās telpiskās konfigurācijas ārtelpu analīze rāda, ka gan telpiskajai struktūrai, gan ēku augstumam ir noteikta ietekme uz izmantošanu. Nenoteikta telpa (undefined space), ko veido deviṇstāvu vai augstāku ēku kvartāli, izrādījās, viens no neveiksmīgākajiem risinājumiem, salīdzinot ar 
analizēto pozitīvo un nenoteikto telpu, ko veido piecstāvu ēku kvartālu izveidotā struktūru kombinācija. Ārtelpas esošās telpiskās konfigurācijas izvērtējums ir būtisks posms jaunu transformāciju plānošanas procesā.

9. Ēkai piegulošās un iedzīvotāju kopīpašumā esošās teritorijas attīstība un labiekārtošana Rīgā lielā mērā ir atkarīga no šo iedzīvotāju vēlmēm un spējām vienoties kopīgiem mērḳiem. Šo kolektīvo lēmumu pieṇemšanas rezultāti saistībā ar publiskās ārtelpas pārveidošanu galvenokārt rezultējas automašīnu stāvvietu izveidē. Jebkura cita iniciatīva, piemēram, ārtelpas labiekārtojums rekreācijai un jauni apstādījumi, parādās kā "partizānu iniciatīvas" jeb privātas aktivitātes, tāpēc tām nevar nodrošināt kvalitāti un drošỉbu.

10. Lai gan Rīgas lielmēroga dzīvojamo rajonu ārtelpā konstatējamas dažādas problēmas, piemēram, neapmierinošs vides pieejamības līmenis, atpūtas iespēju trūkums, atpūtas iespēju monofunkcionalitāte, privātuma trūkums, pašreizējās transformācijas tiecas rast risinājumus tikai daḷai no konstatējamām problēmām. Tādas problēmas kā privātuma trūkums ārtelpā un atpūtas iespēju monofunkcionalitāte, transformācijās neparādās kā prioritātes risinājumu meklēšanai. Tādējādi pirms jaunās transformācijas integrēšanas ir izšķiroša pašreizējo iespēju un iedzīvotāju vajadzību analīze.

11. Jaunā dzīvojamo māju apbūve, kas pārsniedz piecus stāvus, rada riskus mēroga konfliktiem ārtelpā, līdz ar to negatīvi ietekmē lielmēroga dzīvojamo rajonu dzīvojamās vides kvalitāti. Tāpēc apbūves augstuma ierobežojumi lielmēroga dzīvojamo rajonu ārtelpā ir nopietns priekšnoteikums dzīvojamās vides kvalitātes nodrošināšanai arī tajos gadījumos, kad pēc teritorijas izmantošanas noteikumiem jaunai apbūvei ir atḷauts pārsniegt piecus stāvus.

12. Būtisks šķērslis ārtelpas kvalitāti uzlabojošām transformācijām ir zemes îpašumtiesību sadrumstalotais raksturs. Vienas ārtelpas ietvaros zemes gabalu vienības nereti pieder dažādiem īpašniekiem - pašvaldībai, fiziskai vai juridiskai personai, ir kopīpašumā. Dažādiem zemes īpašniekiem ir atšksirīgi zemes īpašumu izmantošanas mērḳi, 
kas rada šķēršlı lus dzīvojamās vides kvalitātes uzlabošanai. Jauni sadarbības model̦i starp privātiem un publiskiem procesa dalībniekiem ir priekšnoteikums visu iesaistīto pušu pozitīvai motivācijai un ārtelpas sabalansētai attīstībai. 


\section{IZMANTOTIE AVOTI}

\section{Grāmatas}

1. Alexander, Ch., Ishikawa, S., Silverstein, M., Jacobson, M., Fiksdahl-King, I., Angel, S. A pattern language: Towns, Buildings, Construction. Oxford: Oxford University Press, 1977. 1171 p. ISBN 978-0195019193.

2. Barker, R. G. Ecological Psychology: Concepts and Methods for Studying the Environment of Human Behavior. Stanford: Stanford University Press, 1968. 252 p. ISBN|978-0804706582.

3. Beer, A., Higgins, C. Environmental planning for site development : A manual for sustainable local planning and design, $2^{\text {nd }}$ edition. London: Routledge, 2000. 368 p. eBook ISBN 9780203639108, https://doi. org/10.4324/9780203639108.

4. Bishop, K., Corkery, L. (eds.). Designing cities with children and young people. London: Routledge, 2017. 278 p. ISBN 9781138890824.

5. Brink̦is, J., Buka, 0. Apbūves kompleksa pilsētplānošanas aspekti : Metodiskie norādījumi arhitektūras bakalaura un profesionālās studiju programmas ietvaros. Rīga: RTU izdevniecība, 2009. 95 lpp.

6. Campbell, A., Converse, P. E., Rodgers, W. L. The quality of American life: perceptions, evaluations and satisfactions. New York: Russell Sage Foundation, 1976. 597 p. ISBN 9781610441032.

7. Carr, S., Francis, M., Rivlin, L. G., Stone, A. M. Public space. Cambridge: Cambridge University Press, 1993. 420 p. ISBN|978-0521359603.

8. Coleman, A. M. Utopia on a trial : Vision and Reality in Planned Housing, $2^{\text {nd }}$ edition, London: Hilary Shipman, 1990. 232 p. ISBN|978-0948096013.

9. Creswell, J.W. Research design : Qualitative, quantitative and mixed methods approaches, 4th edition. London: SAGE Publications, 2014. 342 p. ISBN 978-1-4522-2610-1.

10. Dolley, J., Bosman, C. (eds.). Rethinking Third places : Informal Public Spaces and Community Building. Cheltenham: Edward Elgar Publishing, 2019. 240 p. ISBN|'978-1786433909.

11. Dremaite, M. Baltic Modernism: Architecture and Housing in Soviet Lithuania. Berlin: DOM Publishers, 2017. 250 p. ISBN|978-3869224701.

12. Fischer, C.S., Merton, R.K. The Urban Experience. New York: Houghton Mifflin Harcourt, 1984. 371 p. ISBN|978-0155934986. 
13. Gallent, N., Ciaffi, D. Community action and planning : Contexts, Drivers and Outcomes. Bristol: Lavenham press, 2016. 341 p. ISBN|978-1447315162.

14. Gehl, J. Cities for people. Washington, D.C.: Island press, 2010. 288 p. ISBN|978-1597265737

15. Gehl, J. Life between buildings : Using public space. Washington, D.C.: Island Press, Sixth edition, 2011. 216 p. ISBN 978-1597268271.

16. Gehl, J., Svarre, B. How to study public life. Berlin: Springer, 2013. 200 p. ISBN $\$ 978-1610914239$.

17. Harbusch, G., Perez, M., Somer, K., Weiß , D., Van Es, E. Atlas of the Functional City: CIAM 4 and Comparative Urban Analysis. Zurich: GTA Verlag, 2014. 470 p. ISBN 978-3-85676-338-1.

18. Healey, P. Collaborative planning : Shaping Places in Fragmented Societies. Vancouver: UBC Press, 1997. 446 p. ISBN|978-0774805988.

19. Hess, D., Tammaru, T. (eds.). Housing estates in Baltic countries : The Legacy of Central Planning in Estonia, Latvia and Lithuania. Switzerland: Springer, 2019. 383 p. ISBN 978-3-030-23394-5.

20. Hess, D., Tammaru, T., Van Ham, M. (eds.). Housing Estates in Europe : Poverty, Ethnic segregation and policy challenges. Switzerland: Springer Open, 2018. 429 p. ISBN 978-3-030-06522-5.

21. Heidensohn, F. Crime and Society (Sociology of a Changing world). London: Palgrave, 1989. 228 p. ISBN 9780333435281.

22. Jacobs, J. The death and life of great American cities. UK: Vintage, Reissue edition, 1961. New edition 1992. 458 p. ISBN|978-0679741954.

23. Kaiser, E.J., Godschalk, D.R., Chapin, Jr. F.S. Urban Land Use Planning, $4^{\text {th }}$ edition, Urbana, IL: University of Illinois Press, 1995. 504 p. ISBN 0252021010.

24. Kaplan, R., Kaplan, S. The experience of nature: A psychological perspective, $1^{\text {st }}$ edition. Cambridge: Cambridge University Press, 1989. 352 p. ISBN『978-0521349390.

25. Kliems, A., Dmitrieva, M. (eds.) The Post-socialist city. Continuity and change in urban space and imagery. Berlin: Jovis, 2010. 208 p. ISBN》978-3868590180.

26. Krastiņš, J., Strautmanis, I., Dripe, J. Latvijas arhitektūra no senātnes lìdz mūsdienam. Rīga: Baltika, 1998. 312 lpp. ISBN 9789984917832.

27. Krier, R. Urban Space. New York, NY: Rizzoli, 1979. 174 p. ISBN|978-0847802333.

28. Lang, J., Marschall, N. Urban squares as places, links and displays: Successes and failures, $1^{\text {st }}$ edition. London: Routeledge, 2016. 310 p. ISBN 9781138959293. 
29. Lefcourt, H. (ed). Locus of Control: Current Trends in Theory \& Research. New York: Halsted Press, 1976. 268 p. ISBN 9780898592221.

30. Light, A., Smith, J. Philosophy and Geography II: The Production of Public Space. Lanham: Rowman and Littlefield, 1998. 268 p. ISBN 『978-0847688104.

31. Little, C.E. Greenways for America (Creating the North American Landscape). Baltimore, MD, USA: JHU Press, 1995. 288 p. ISBN 『978-0801851407.

32. Lynch, K. Good city form. Cambridge: The MIT Press, 1984. 514 p. ISBN|978-0262620468.

33. Lynch, K., Hack, G. Site Planning, $3^{\text {rd }}$ Edition. Cambridge: MIT Press, 1984. 450 p. ISBN|978-0262121064.

34. Madanipour, A. Cities in Time, Temporary urbanism and the future of the city. London: Bloomsbury publishing, 2017. 198 p. ISBN|978-1474220712.

35. Madden, K., Schwartz, A. Project for Public Spaces. How to Turn a Place Around: A Handbook of Creating Successful Public Spaces. New York: Project for Public Spaces, 2000.121 p. ISBN 9780970632401.

36. Marans, R., Stimson, R. (eds.). Investigating Quality of Urban Life: Theory, Methods, and empirical research. New York: Springer, 2011. 453 p. ISBN 978-94-007-1742-8.

37. Matthews, M.H. Making sense of place: children's understanding of large-scale environments. Birmingham: Harvester Wheatsheaf, 1992. 271 p. ISBN 978-0745009315.

38. Meuser, P., Zadorin, D. Towards a Typology of Soviet Mass Housing: The set: Prefabrication in the USSR 1955-1991. Berlin: DOM Publishers, 2016. 455 p. ISBN 978-3869224466.

39. Montgomery, Ch. Happy Cities: Transforming our lives through urban design. New York: Farrar, Straus and Giroux, 2013. 369 p. ISBN 978-0374534882.

40. Moravanszky, A., Kegler, K.R. (eds.) Re-scaling the environment: new landscapes of design, 1960-1980 (East West Central: Re-building Europe, 1950-1990). Basel: Birkhauser Architecture, 2016. 320 p. ISBN 978-3035610161.

41. Newman, 0. Defensible space: Crime prevention through urban design. New York: Macmillan Publishing, 1973. 264 p. ISBN 978-0020007500.

42. Otrā Rìga : Dzīvojamo mikrajonu attīstības perspektīvas [Red.: I. Pedece, B. Gēbele, P. Strancis, G. Princis, G. Asaris, S. Treija, M. Liepa]. Rìga, Latvija, 2004. 96 lpp.

43. Pacione, M. Urban Geography: A global perspective. Second edition. New York: Routledge, 2005. 957 p. ISBN 9780415462020. 
44. Paddison, R., Miles, S. Culture-led urban regeneration. New York: Routledge, 2009. 186 p. ISBN 9780415568524.

45. Perloff, H.S. The Quality of the urban environment: Essays on new resources in an urban age. New York: RFF Press, 1969. 352 p. ISBN 9781138930438.

46. Power, A. Estates on the Edge: the social consequences of mass housing in Northern Europe. London: Palgrave Macmillan, 1997. 456 p. ISBN 9780333746035.

47. Prak, N., Priemus, H. Post-war public housing in trouble: Papers presented at the congress "Post-war public housing in trouble," Delft, the Netherlands, October 4-5, 1984. Delft: Delft university press, 1986. 200 p. ISBN 978-9062751679.

48. Rosenberg, M. J., Hovland, C. I. Cognitive, affective and behavioural components of attitudes [In: C. I. Hovland \& M. J. Rosenberg (eds.)], Attitude, organization and change. New Haven, CT: Yale University Press, 1960. pp. 1-14. ISBN 9780300008647.

49. Rowlands, R., Musterd, S., Van Kempen, R. (eds.). Mass Housing in Europe: multiple faces of development, change and response. London: Palgrave Macmillan, 2009. 285 p. ISBN 9780230007307.

50. Schaffer, D., Vollmer, D. Pathways to urban sustainability: research and development on urban systems. Washington D.C.: National academy press, 2010. 124 p. ISBN 978-0-309-15895-4, 978-0-309-16151-0, https://doi.org/10.17226/12969

51. Sennett, R. The conscience of the Eye, the design and social life of cities. New York: Alfred Knopf, 1990. 284 p. ISBN 978-0393308785.

52. Shirvani, H. The urban design process. New York: Van Nostrand Reinhold Company, 1985, 192 p. ISBN 978-0442280642.

53. Sitte, C. City Planning According to Artistic Principles [translated by G. R. Collins and C. C. Collins]. London: Phaidon, 1889 [1965].

54. Smithson, P. Planning today. In: Architectural design, 1957. p. 185-190.

55. Stake, R. E. The art of case study research. Thousand Oaks, CA: Sage, 1995. 192 p. ISBN 978-0803957671.

56. Tsenkova, S., Lowe, S. Housing Change in East and Central Europe: Integration or Fragmentation? London: Routeledge, 2003. 244 p. ISBN 978-0754618140.

57. Tiesdel, S., Carmona, M. Urban design reader. London: Routledge, 2006. 384 p. ISBN 978-0750665315, https://doi. org/10.4324/9780080468129 
58. Van Kempen, R., Dekker, K., Hall, S., Tosics, I. Restructuring large housing estates in Europe: Restructuring and resistance inside the welfare industry. Bristol: Policy Press, 2005. 400 p. ISBN 978-1861347756.

59. Wang, X., vom Hofe, R. Research Methods in Urban and Regional Planning. Berlin: Springer, 2007. 430 p. ISBN 978-3-540-49658-8, https://doi.org/10.1007/978-3-540-49658-8

60. Whyte, W. The social life of small urban spaces. New York: Project for public spaces, 2001. 125 p. ISBN 978-0970632418.

61. Wise, N., Clark, J. (ed.) Urban Transformations: Geographies of Renewal and Creative Change. London: Routledge, 2019. 238 p. ISBN 9780367877927.

62. Yin, R. K. Case study research: Design and methods. $3^{\text {rd }}$ edition. Thousand Oaks, CA: Sage, 2002. 200 p. ISBN 978-1-4129-6099-1.

63. Zuker, P. Town and Square: From the Agora to the Village Green. New York: Columbia university press, 1959. 287 p. ISBN 978-0262740050.

64. Адамчевска-Вейхерт, $\mathbf{X}$. Формирование жилых комплексов. Москва: Стройиздат, 1988. 304 стр.

65. Машинский, В.Л.; Залогина, Е.Г. Проектирование озеленения жилых районов. Москва: Стройиздат, 1978. 112 стр.

Zinātniskie raksti žurnālos, rakstu krājumos, konferenču materiālos, pētijumi

66. Aalbers, M., van Beckhoven, E., van Kempen, R., Musterd, S., Ostendorf, W.J.M. Large housing estates in Netherlands. Overview of developments and problems in Amsterdam and Ultrecht. RESTATE Report 2e, RESTATE Reports, 2003. 154 p.

67. Aalbers, M., Rancati, S. Feeling insecure in large housing estates: Tackling "Unsicherheit" in the Risk Society. Urban studies, Vol. 45, No. 13, 2008, pp. 2735-2757.

68. Adriaanse, C.C.M. Measuring residential satisfaction: A residential environmental satisfaction scale (RESS). Journal of Housing and the Built Environment, 22 (3), 2007, pp. 287-304. https://doi.org/10.1007/ s10901-007-9082-9.

69. Alterman, R. The challenge of farmland preservation: Lessons from a six-nation comparison. Journal of the American Planning Association, 63 (2), 1997, pp. 220-243.

70. Araya, R., Montgomery, A., Rojas, G., Fritsch, R., Solis, J., Signorelli, A., Lewis, G. Common mental disorders and the built environment in Santiago Chile Br. J. Psychiatry., 190 (2007), pp. 394-401. 
71. Artmann, M., Kohler, M., Meinel, G., Gan, J., Ioja, I.-C. How smart growth and green infrastructure can mutually support each other A conceptual framework for compact and green cities. Ecol. Indicators, 96 (2), 2019, pp. 10-22. https://doi.org/10.1016/j.ecolind.2017.07.001.

72. Atkinson, R. Discourses of partnership and empowerment in contemporary British urban regeneration. Urban Studies, Vol. 36, Issue 1, 1999, pp. 59-72. https://doi.org/10.1080/0042098993736.

73. Aziz, N. F., Said, I. The trends and influential factors of children's use of outdoor environments: A review. Procedia - Social and Behavioral Sciences, 38, 2012, pp. 204-212. https://doi.org/10.1016/j. sbspro.2012.03.341.

74. Beckhoven, E., Bolt, G., van Kempen, R. Theories of neighbourhood change and decline: their significance for post-WWII large housing estates. Conference proceedings "Housing in Europe: New Challenges and Innovations in Tomorrow's Cities", Reykjavik, 29 June - 2 July, 2005, pp. 1-25.

75. Bendjedidi, S., Bada, Y., Meziani, R. Open spaces: spatial configuration, visibility analysis and use: case study of mass housing in Biskra, Algeria. International review for spatial planning and sustainable development, 6/4, 2018, pp. 93-109. https://doi. org/10.14246/irspsd.6.4_93.

76. Benedict, M.A., McMahon, E.T. Green infrastructure: Smart conservation for the $21^{\text {st }}$ century. Renew. Resour. J., 20, 2002, pp. 12-17.

77. Bengston, D.N., Fletcher, J.O., Nelson, K.C. Public policies for managing urban growth and protecting open space: Policy instruments and lessons learned in the United States. Landscape and Urban Planning, 69 (2), 2004, pp. 271-286.

78. Bodnar, J., Molnar, V. Reconfiguring private and public state, capital and new housing development in Berlin and Budapest. Urban Studies, Volume: 47, issue: 4, 2010, pp. 789-812.

79. Bonaiauto, M., Fornara, F., Bonnes, M. Indexes of perceived residential environment quality and neighbourhood attachment in urban environments: a confirmation study on the city of Rome. Landscape and urban planning, 65, 2003, pp. 41-52. https://doi. org/10.1016/S0169-2046(02)00236-0.

80. Bonaiuto, M., Fornara, F., Ariccio, S., Cancellieri, U.G., Rahimi, L. Perceived Residential Environment Quality Indicators (PREQIs) relevance for UN-HABITAT City Prosperity. Habitat International, Vol. 45, Part 1, 2015, pp. 53-63. https://doi.org/10.1016/j. habitatint.2014.06.015. 
81. Bonaiauto, M., Fornara, F., Bonnes, M. Perceived residential environment quality in middle- and low-extension italian cities = Perception de la qualité résidentielle dans les villes italiennes de moyenne et petite étendues. European review of applied psychology, Vol. 56, Issue 1, 2006, pp. 23-34. https://doi.org/10.1016/j. erap.2005.02.011.

82. Bonnes, M., Bonaiuto, M., Aiello, A., Perugini, M., Ercolani, A.P. A transactional perspective on residential satisfaction. Housing Surveys. Advances in Theory and Methods [In: Despres, C., Piché, D. (eds.),], Québec: Centre de recherche en aménagement et développement: Université de Laval, 1997, pp. 99-13.

83. Brueckner, J.K. Urban sprawl: Diagnosis and remedies. International Regional Science Review, 23, 2000, pp. 160-171.

84. Burton, E.J., Weich, S., Bianchard, M., Prince, M. Measuring Physical Characteristics of housing: The built environment site survey checklist (BESSC). Environmental and planning B: Planning and Design, Vol. 32, Issue 2, 2005, pp. 265-280. https://doi.org/10.1068/b3038.

85. Caldenby, C. Architecture and society. White architects and Swedish post-war architecture. Proceedings of the $15^{\text {th }}$ International Docomomo Conference - Metamorphosis: The Continuity of Change, 15IDC, Ljubljana, Slovenia, 28-31 August 2018, pp. 76-84.

86. Carmona, M. Principles for public space design, planning to do better. Urban design International, 24, 2019, pp. 47-59. https://doi. org/10.1057/s41289-018-0070-3.

87. Carmona, M. Contemporary public space, Part two: classification. Journal of urban design, 15:2, 2010, pp. 157-173. http://dx.doi. org/10.1080/13574801003638111.

88. Carmona, M. Contemporary public space: Critique and classification, Part one: critique. Journal of Urban Design, 15:1, 2010, pp. 123-148. https://doi.org/10.1080/13574800903435651.

89. Cao, J.X., Wang, D. Environmental correlates of residential satisfaction: An exploration of mismatched neighborhood characteristics in the Twin Cities. Landscape and Urban Planning, Vol. 150, 2016, pp. 26-35. https://doi.org/10.1016/j. landurbplan.2016.02.007.

90. Cavanagh, W. Empty space? Courts and squares in Mycenaean towns. Urbanism in the Aegean Bronze Age; Sheffield Studies in Aegean Archaeology, Vol. 4., [In: K. Branigan ed.]., Sheffield, UK: Sheffield Academic Press, 2001, pp. 119-134.

91. Debek, M., Janda-Debek, B. Perceived Residential Environment Quality and Neighborhood Attachment (PREQ \& NA) Indicators by Marino Bonaiuto, Ferdinando Fornara, and Mirilia Bonnes - Polish 
adaptation. Polish Journal of Applied Psychology, Vol. 13, Issue 2, 2015, pp. 1-52. https://doi.org/10.1515/pjap-2015-0032.

92. Dekker, K., de Vos, S., Musterd, S., van Kempen, R. Residential satisfaction in housing estates in European cities: A multi-level research approach. Housing Studies, 26(4),2011, pp. 479-499. https:// doi.org/10.1080/02673037.2011.559751.

93. Dunstan, F., Weaver, N., Araya, R., Bell, T., Lannon, S., Lewis, G., Patterson, J., Thomas, P., Jones, P., Palmer, S. An observation tool to assist with the assessment of urban residential environments. Journal of Environmental Psychology, Vol. 25, Issue 3, 2005, pp. 293-305. https://doi.org/10.1016/j.jenvp.2005.07.004.

94. Dzhambov, A.M., Hartig, T., Tilov, B., Atanasova, V., Makakova, D.R., Dimitrova, D.D. Residential greenspace is associated with mental health via intertwined capacity-building and capacity-restoring pathways. Environmental research, Vol. 178, 2019, p. 108708. https://doi.org/10.1016/j.envres.2019.108708.

95. Edwards, N., Hooper, P., Trapp, G.A., Bull, F., Boruff, B., Giles-Corti, B. Development of a public open space desktop auditing tool (POSDAT): a remote sensing approach. Applied geography, Vol. 38, 2013, pp. 22-30. https://doi.org/10.1016/j.apgeog.2012.11.010.

96. El Din, H.S., Shalaby, A., Farouh, H.E., Elariane, S.A. Principles of urban quality of life for a neighbourhood. HBRC Journal, Vol. 9, Issue 1, 2013, pp. 86-92. https://doi.org/10.1016/j.hbrcj.2013.02.007.

97. Ferreira, I.A., Johansson, M., Sternudd, C., Fornara, F. Transport walking in urban neighbourhoods-Impact of perceived neighbourhood qualities and emotional relationship. Landscape and urban planning, Vol. 150, 2016, pp. 60-69. https://doi.org/10.1016/j. landurbplan.2016.02.009.

98. Finlay, J., Esposito, M., Li, M., Colabianchi, N., Zhou, H., Judd, S., Clarke, P. Neighbourhood active aging infrastructure and cognitive function: a mixed-methods study of older Americans. Preventive medicine, Vol. 150, 2021, 106669. https://doi.org/10.1016/j. ypmed.2021.106669.

99. Florida, R., Mellander, C., Stolarick, K. Beautiful Places: The Role of Perceived Aesthetic Beauty in Community Satisfaction. Regional Studies, 45, (1), 2011, pp. 33-48. https://doi.org/10.1080/00343404.2 010.486784 .

100. Fornara, F., Bonaiauto, M, Bonnes, M. Cross-Validation of Abbreviated Perceived Residential Environment Quality (PREQ) and Neighborhood Attachment (NA) Indicators. Environment and Behavior, 42, (2), 2010, pp.171-196. https://doi. org/10.1177/0013916508330998. 
101. Foster, S., Giles-Corti, B., Knuiman, M. Neighbourhood design and fear of crime: A social-ecological examination of the correlates of residents' fear in new suburban housing developments. Health and Place, Vol. 16, Issue 6, 2010, pp. 1156-1165. https://doi.org/10.1016/j. healthplace.2010.07.007.

102. Gifford, R. Residential environmental psychology. In: Gifford, R. (ed.) Environmental psychology: Principles and practice, 5th ed., Colville (Washington): Optimal Books, 2014. pp. 212-239.

103. Godhwani, S., Jivraj, S., Marshall, A., Becares, L. Comparing subjective and objective neighbourhood deprivation and their association with health over time among older adults in England. Health and Place, 2019, Vol. 55, pp. 51-58. https://doi.org/10.1016/j. healthplace.2018.10.006.

104. Gong, Y., Palmer, S., Gallacherc, J., Marsdena, T., Foneb, D. A systematic review of the relationship between objective measurements of the urban environment and psychological distress. Environment international, Vol. 96, 2016, pp. 48-57. https://doi. org/10.1016/j.envint.2016.08.019.

105. Gorczyca, K. The Social Transformation of Large Housing Estates in Poland at the Turn of the $21^{\text {st }}$ Century. Czech sociological review, 52, (6), 2016, pp. 861-892. https://doi.org/10.13060/00380288.2016.52.6.28 9.

106. Hall, S., Murie, A., Rowlands, R., Sankey, S. Large housing estates in London and Birmingham, UK, Opinions of residents on recent developments. Restate report 4j. Utrecht: University Utrecht, Faculty of Geosciences, 2005. 118 p. [cited 10.02.2019]. http://restate.geo.uu.nl/ results/Report4/4kec.pdf.

107. He, L. Paez, A., Liu, D. Built environment and violent crime: An environmental audit approach using Google Street. Computers, Environment and Urban systems, 66, 2017, pp. 83-95. https://doi. org/10.1016/j.compenvurbsys.2017.08.001.

108. Hedayati, M., Abdullah, M.A., Ignatius, J., Tilaki, M.J.M. Examining the effects of crime prevention through environmental design (CPTED) on Residential Burglary. Int. journal of law, crime and justice, Vol. 46, 2016, pp. 86-102. https://doi.org/10.1016/j.ijlcj.2016.04.001.

109. Huang, S. C. L. A study of outdoor interactional spaces in high-rise housing. Landscape and Urban Planning, 78, 2006, pp. 193-204. https:// doi.org/10.1016/j.landurbplan.2005.07.008.

110. Irwin, E. G., Bockstael, N.E. Land use externalities, open space preservation, and urban sprawl. Regional Science and Urban Economics, 34 (6), 2004, pp. 705-725. 
111. Jansen, S. J. T. Why is housing always satisfactory? A study into the impact of cognitive restructuring and future perspectives on housing appreciation. Social Indicators Research, 116, 2014, pp. 353-371. https://doi.org/10.1007/s11205-013-0303-1.

112. Jaskiewicz, M., Wiwatowska, E. Perceived neighbourhood disorder and quality of life: the role of the human-place bond, social interactions, and out-group blaming, Journal of environmental psychology, Vol. 58, 2018, pp. 31-41. https://doi.org/10.1016/j. jenvp.2018.07.008.

113. Kabisch, S., Grossmann, K. Challenges for large housing estates in light of population decline and ageing: Results of a long-term survey in East Germany. Habitat International, Vol. 39, 2013, pp. 232-239. https://doi.org/10.1016/j.habitatint.2012.12.003.

114. Kajumulo Tibaijuka, A. Interactive Discussion with Heads of UN Programmes and Agencies: Responding to the Challenges. $12^{\text {th }}$ Session of the Commission on Sustainable Development, New York, USA, 29 April 2004, 5 p. [online, cited 10.11.2019]. https://sustainabledevelopment. un.org/content/documents/habitat_2904.pdf

115. Kaplan, $\mathbf{S}$. The restorative benefits of nature: Toward an integrative framework, Journal of Environmental Psychology, 15 (3), 1995, pp. 169-182, ISSN 0272-4944, https://doi.org/10.1016/02724944(95)90001-2.

116. Kienast, F., Degenhardt, B., Weilenmann, B., Wäger, Y., Buchecker, M. GIS-assisted mapping of landscape suitability for nearby recreation. Landscape and urban planning, Vol. 105, Issue 4, 2012, pp. 385-399. https://doi.org/10.1016/j.landurbplan.2012.01.015.

117. Kilnarova, P., Wittmann, M. Open Space between Residential Buildings as a Factor of Sustainable Development - Case Studies in Brno (Czech Republic) and Vienna (Austria). IOP Conference Series: Earth and Environmental Science, Vol. 95, Issue 5, 2017, pp. 2-12. doi :10.1088/1755-1315/95/5/052008.

118. Knack, R.E. Hanging out: teens search for the perfect public space. Planning, 66 (8), 2000, pp. 4-9.

119. Korpela, K., Borodulin, K., Neuvonen, M., Paronen, O., Tyrväinen, L. Analyzing the mediators between nature-based outdoor recreation and emotional well-being. Journal of environmental psychology, Vol. 37, 2014, pp. 1-7. https://doi.org/10.1016/j.jenvp.2013.11.003.

120. Kosunen, H., Hirvonen-Kantola, S., Hentilä, H-L. Approaches to planning urban infill on Finnish large housing estates. The Finnish society of urban planning [online, cited 10.05.2020]. https://www.yss. fi/journal/approaches-to-planning-urban-infill-on-finnish-largehousing-estates/ 
121. Koomen, E., Dekkers, J., van Dijkc, T. Open-space preservation in the Netherlands: Planning, practice and prospects. Land Use Policy, 25 (3), 2008, pp. 361-377.

122. Kristiánová, K. Post-Socialist Transformations of Green Open Spaces in Large Scale Socialist Housing Estates in Slovakia. Procedia engineering, Vol. 161, 2016, pp. 1863-1867. https://doi.org/10.1016/j. proeng.2016.08.715.

123. Laws, D., Scholz, R. W., Shiroyama, H., Susskind, L., Suzuki, T., Weber, 0. Expert views on sustainability and technology implementation. The International Journal of Sustainable Development \& World Ecology, 2004, Vol. 11, Issue 3, pp. 247-261. https://doi. org/10.1080/13504500409469829.

124. Lennard, S.H.C. Lennard, H.L. Livable Cities: People and Places: Social and Design Principles for the Future of the City. Center for Urban Well-Being. Venice: Gondolier Press, 1987. 166 p.

125. Lipnik Vehovar, K. Modern neighbourhoods in Ljubljana - The splendour and misery of their existence and development. Proceedings of the $15^{\text {th }}$ International Docomomo Conference - Metamorphosis: The Continuity of Change, 15IDC, 2018, pp. 156-163.

126. Llinares, C., Page, A., Llinares, J. An approach to defining strategies for improving city perception. Case study of Valencia, Spain. Cities, Vol. 35, 2013, pp. 78-88. https://doi.org/10.1016/j.cities.2013.06.009.

127. Lūse, M. Latvijas pilsētu dzīvojamo kvartālu apstādījumu izmantošana. Arhitektūra un pilsētbūvniecība Latvijas PSR. Rīga: Zinātne, 1971, 159. -174.lpp.

128. Lu, M. Determinants of Residential Satisfaction: Orderd Logit vs. Regression Models. Growth and Change, 30, 1999, pp. 264-287.

129. Madanipour, A. Marginal public spaces in European cities. Journal of Urban Design, Vol. 9. No. 3, 2004, pp. 267-286.

130. Malone, K. "Street Life: Youth" Culture and Competing Uses of Public Space. Environment and Urbanization, 14 (2), 2002, pp. 157-168.

131. Marans, R., Rodgers, W. Towards an understanding of community satisfaction. In: Metropolitan America in contemporary perspective (Eds.: A.H. Hawley, V.P. Roch), New York: Halstead Press, 1975. pp. 89-101.

132. Markevych, I., Schoierer, J., Hartig, T., Chudnovsky, A., Hystad, P., Dzhambov, A.M., de Vires, S., Triguero-Mas, M., Brauer, M. et al. Exploring pathways linking greenspace to health: Theoretical and methodological guidance. Environmental research, 2017, 158, pp. 301-317. https://doi.org/10.1016/j.envres.2017.06.028. 
133. Marin. V., Chelcea, L. The Many (Still) Functioning Housing estates in Bucharest, Romania: a viable housing provider in Europe's densest capital city. Housing Estates in Europe: poverty, segregation, and policy challenges [In: Hess DB, Tammaru T, van Ham M (eds.)]. Springer, Dordrecht, Netherlands, 2018, pp. 167-190.

134. Marshall, K.A., Gonzalez-Meler, M.A. Can ecosystem services be part of the solution to environmental justice? Ecosystem services, Vol. 22, Part A, 2016, pp. 202-203. https://doi.org/10.1016/j. ecoser.2016.10.008.

135. Maruani, T., Amit-Cohen, I. Open space planning models: A review of approaches and methods. Landscape and Urban Planning, 81, 2007, pp. 1-13.

136. Mccrea, R., Stimson, R., Western, J. "Testing a Moderated Model of Satisfaction with Urban Living using Data for Brisbane-South East Queensland, Australia". Social Indicators Research: An International and Interdisciplinary Journal for Quality-of-Life Measurement, Springer, Vol. 72 (2), 2005, pp. 121-152. https://doi.org/10.1007/ s11205-004-2211-x.

137. McLintock, M. Maximising the benefits of green infrastructure in social housing. Scottish Natural Heritage Research Report No. 1046. 2018. $98 \mathrm{p}$.

138. Metspalu, P., Hess, D.B. Revisiting the role of architects in planning large-scale housing in the USSR: the birth of socialist residential districts in Tallinn, Estonia, 1957-1979. Planning perspectives, 33 (3), 2017, pp. 335-361. https://doi.org/10.1080/02665433.2017.1348974.

139. Milgram, S. The experience of living in cities. Science, 167, 1970, pp. 1461-1468.

140. M. Dębek, B. Janda-Dębek, Perceived Residential Environment Quality and Neighborhood Attachment (PREQ \& NA) Indicators by Marino Bonaiuto, Ferdinando Fornara, and Mirilia Bonnes - Polish adaptation. Polish Journal of Applied Psychology 2015, vol. 13 (2). pp. 1-52. https://doi.org/10.1515/pjap-2015-0032.

141. Moore, T.H.M., Kesten, J.M., Lopez-Lopez, J.A., Ijaz, S., McAleenan, A., Richards, A., Gray, S., Savovis, J., Audrey, S. The effects of changes to the built environment on the mental health and well-being of adults: Systematic review. Health and Place, Vol. 53, 2018, pp. 237-257. https://doi.org/10.1016/j.healthplace.2018.07.012.

142. Moser, G. Quality of life and sustainability: Toward personenvironment congruity. Journal of Environmental Psychology, Vol. 29, Issue 3, 2009, pp. 351-357. https://doi.org/10.1016/j. jenvp.2009.02.002. 
143. Musterd, S., van Kempen, R. Large housing estates in European cities. Opinions of residents on recent developments. Restate report 4k. RESTATE reports. Netherlands: Urban and regional research center, 2005. 118 p. [cited 10.02.2019]. http://restate.geo.uu.nl/results/ Report4/4kec.pdf.

144. Nazir, N.N.M., Othman, N., Nawawi, A.H. Green Infrastructure and its Roles in Enhancing Quality of Life. Procedia - Social and Behavioral Sciences, Vol. 153, 16 October 2014, pp. 384-394. https://doi. org/10.1016/j.sbspro.2014.10.071.

145. Nechyba, T.J. Walsh, R.P. Urban sprawl. Journal of Economic Perspectives, Vol. 18, No. 4, 2004, pp. 177-200.

146. Nickelson, J., Wang, A.R., Mitchell, Q.P., Hendricks, K., Paschal, A. Inventory of the physical environment domains and subdomains measured by neighborhood audit tools: A systematic literature review. Journal of Environmental Psychology, Vol. 36, December 2013, pp. 179-189. https://doi.org/10.1016/j.jenvp.2013.07.009.

147. Öresjö, E., Andersson, R., Holmqvist, E., Pettersson, L., Siwertsson, Ch. Large Housing Estates in the Sweden: Policies and Practices. RESTATE report 3 (D5/6). Ultrecht: Faculty of Geosciences, Utrecht University, 8 January 2004, 2004. 84 p. [cited 10.02.2019]. https://doi. org/10.13140/RG.2.1.4550.0562.

148. Pacione, M. Urban environmental quality and human wellbeing-a social geographical perspective. Landscape and urban planning, 65, 2003, pp. 19-30.

149. Parkes, A., Kearns, A., Atkinson, R. What makes people dissatisfied with their neighbourhoods? Urban Studies, 39 (13), 2002, pp. 2413-2438. https://doi.org/10.1080/004209802200002703.

150. Pauleit, S., Ambrose-0ji, B., Andersson, E., Anton, B., Biijs, A., Haase, D., Elands, B., Hansen, R., Kowarik, I., Kronenberg, J., Mattijssen, T., Olafsson, A.S., Rall, E., van der Jagt, A.P.N., van der Bosch, C.K. Advancing urban green infrastructure in Europe: Outcomes and reflections from the GREEN SURGE project. Urban forestry and greening, Vol. 40, 2019. pp. 4-16. https://doi. org/10.1016/j.ufug.2018.10.006.

151. Perkins, D.D. The physical environment of street blocks and resident perceptions of crime and disorder: Implications for theory and measurement. Journal of Environmental Psychology, 1992. pp. 21-34.

152. Perkins, D.D., Taylor, R.B. Revised Block Environmental Inventory (RBEI) [online, cited 10.01.2019]. https://cdn.vanderbilt.edu/vu-my/ wp-content/uploads/sites/249/2011/09/14093050/BEI.2.doc. 
153. Perkins, D.D., Larsen, C., Brown, B. Mapping Urban Revitalization: Using GIS Spatial Analysis to Evaluate a New Housing Policy. Journal of Prevention \& Intervention Community, 37 (1), 2009, pp. 48-65. https:// doi.org/10.1080/10852350802498698.

154. Poortinga, W. et al. Neighborhood Quality and Attachment: Validation of the Revised Residential Environment Assessment Tool. Environment and behaviour, Vol. 49, Issue 3, 2016. pp. 1-28. https://doi. org/10.1177/0013916516634403.

155. Püffel, C., Haase, D., Priess, J. Mapping Ecosystem Services on Brownfields in Leipzig, Germany. Ecosyst. Serv., 30, 2018, pp. 73-85. https://doi.org/10.1016/j.ecoser.2018.01.011.

156. Qingfen, W. Outdoor Activity Space Design for the Elderly in Residential Areas. 2019 International Conference on Intelligent Transportation, Big Data \& Smart City (ICITBS), 2019, pp. 278-280. https://doi.org/10.1109/ICITBS.2019.00073.https://ieeexplore.ieee. org/document/8669627.

157. Quintas, R., Koutsogeorgou, E., Raggi, A., Bucciarelli, P., Cerniauskaite, M., Leonardi, M. The selection of items for the preliminary version of the COURAGE in Europe built environment instrument. Maturitas: An International journal of midlife health and beyond, Vol. 71, Issue 2, 2012, pp. 147-153. https://www.maturitas. org/article/S0378-5122(11)00399-9/fulltext.

158. Rehdanz, K., Maddison, D.J. Local Environmental Quality and Life-Satisfaction in Germany. Ecological Economics, 64 (4), 2008, pp. 787-797. https://doi.org/10.1016/j.ecolecon.2007.04.016.

159. Repetti, A., Desthieux, G. A Relational Indicator set Model for urban land-use planning and management: Methodological approach and application in two case studies. Landscape and Urban Planning, Vol. 77, Issue 1-2, 2006, pp. 196-215. https://doi.org/10.1016/j. landurbplan.2005.02.006.

160. Rivlin, L.G. Public spaces and public life in urban areas. The urban experience: a people-environment perspective [In; S.J. Neary, M.S. Symes and F.E. Brown eds.], Taylor \& Francis group, 1994, pp. 289-296.

161. Rodiek, S. SOS Senior's outdoor survey. Texas, TX: Center for health systems and design, 2014 [online, cited 10.01.2019]. https://www. accesstonature.org/SOS-ENGLISH.pdf.

162. Rowland, R., Murie, A. Whose Regeneration? The Spectre of Revanchist Regeneration. Mass Housing in Europe [In: Rowlands R., Musterd S., van Kempen R. (eds)]. London: Palgrave Macmillan, 2009. pp. 235-264. 
163. Salingaros, N., Pagliardini, P. Geometry and life of urban space. Proceedings of the 11th International Congress on the Virtual City and Territory, "Back to the Sense of the City", Krakow, Poland, 6-8 July 2016. pp. 1-20.

164. Salama, A., Azzali, S. Examining attributes of urban open spaces in Doha. Proc. ICE-Urban Design and Planning, 168 (2), 2015, pp. 75-87.

165. Sampson, R. J., Raudenbush, S.W. Systematic social observation of public spaces: A new look at disorder in urban neighborhoods. American Journal of Sociology, 105, no. 3, 1999, pp. 603-651.

166. Schaefer-McDaniel, N., Caughy, M.O., O'Campo, P., Gearey, W. Examiningmethodological details of neighbourhood observations and the relationship tohealth: a literature review. Soc Sci Med, 70, 2010. pp. 277-292.

167. Schaefer-McDaniel, N., Dunn, J.R, Minian, N, Katz, D. Rethinking measurement of neighborhood in the context of health research. Soc Sci Med, 71, 2010, pp. 651-656.

168. Seamon, D., Sowers, J. Place and Placelessness, Key Texts in Human Geography, [In P. Hubbard, R. Kitchen, \& G. Vallentine, eds.], London: Sage, 2008, pp. 43-51.

169. Sendi, R., Goličnik Marušić, B. Neighbourhood design. International Encyclopedia of Housing and Home, Elsevier Science, 2012. 3862 p.

170. Sendi, R., Marušić, B. Neighbourhood Design. Public Spaces. International encyclopedia of housing and home, 2012, pp. 21-28. https://doi.org/10.1016/B978-0-08-047163-1.00541-5.

171. Sendi, R. Housing Reform and Housing conflict: the privatization and denationalization of public housing in the republic of Slovenia in practice. Intern. Journal of urban and regional research, Vol. 19, No. 3, 1995. pp. 435-446.

172. Shu-Chun, L.H. A study of outdoor international spaces in high-rise housing. Landscape and Urban Planning, Vol. 78 (3), 2006, pp. 193-204. https://doi.org/10.1016/j.landurbplan.2005.07.008.

173. Shabak, M., Norouzi, N., Abdullah, A.M., Khan, T.H. Children's sense of attachment to the residential common open space. Procedia Social and Behavioral Sciences, 201:39-48, 2015. https://doi. org/10.1016/j.sbspro.2015.08.117

174. Silva, C., Viegas, I., Panagopoulos, T., Bell, S. Environmental Justice in Accessibility to Green Infrastructure in Two European Cities. Land, Vol. 7, 134, 2018, pp. 1-23. https://doi.org/10.3390/land7040134.

175. Skalicky, V., Čerpes, I. Comprehensive assessment methodology for liveable residential environment. Cities, Vol. 94, 2019, pp. 44-54. https://doi.org/10.1016/j.cities.2019.05.020. 
176. Skjaeveland, 0., Garling, T. Effects of interactional space on neighbouring. Journal of environmental psychology, 17 (3), 1997, p. 181-198. https://doi.org/10.1006/jevp.1997.0054.

177. Sola, A.G., Vilhelmson, B. Negotiating Proximity in Sustainable Urban Planning: A Swedish Case. Sustainability, Vol. 11 (1), 2019. p. 31. https://doi.org/10.3390/su11010031.

178. Spokane, A.R., Lombard, J.L., Martinez, F., et al. Identifying streetscape features significant to well-being. Architectural science review, 50 (3), 2007, pp. 234-245. https://doi.org/10.3763/ asre.2007.5029.

179. Stanley, B.W., Stark, B.L., Johnston, K.L., Smith, M.E. Urban Open Spaces in Historical Perspective: A Transdisciplinary Typology and Analysis. Urban Geography, 33 (8), 2012, pp. 1089-1117. https://doi. org/10.2747/0272-3638.33.8.1089.

180. Sterling, E.J., Betley, E., Sigouin, A., Gomez, A., Toomey, A., Cullman, G., Malone, C., Pekor, A., Arengo, F., Blair, M., Filardi, C., Landrigan, K., Luz Porzecanski, A. Assessing the evidence for stakeholder engagement in biodiversity conservation. Biological Conservation, Vol. 209, 2017, pp. 159-171. https://doi.org/10.1016/j.biocon.2017.02.008.

181. Suarez, M., Barton, D.N., Cinburova, Z., et al. Environmental justice and outdoor recreation opportunities: a spatially explicit assessment in Oslo metropolitan area, Norway. Env. Science and policy, Vol. 108, 2020, pp. 133-143. https://doi.org/10.1016/j.envsci.2020.03.014.

182. Temelova, J., Slezakova, A. The changing environment and neighbourhood satisfaction in socialist high-rise panel housing estates: The time-comparative perceptions of elderly residents in Prague. Cities, Vol. 37, 2014, pp. 82-91. https://doi.org/10.1016/j. cities.2013.12.002.

183. Tiitu, M., Viinikka, A., Kopperoinen, L., Geneletu, D. Balancing urban green space and residential infill development: a spatial multi-criteria approach based on practitioner engagement. Journal of Env.Ass. Policy and Management, Vol. 20, 03, 2018, p. 1840004. https:// doi.org/10.1142/S1464333218400045.

184. Trojanek, R., Gluszak, M., Tanas, J. The effect of urban green spaces on house prices in Warsaw. International Journal of Strategic Property Management, 22 (5), 2018, pp. 358-371. https://doi.org/10.3846/ ijspm.2018.5220.

185. Turan, S.ö., Pulatkan, M., Beyazlı, D., Özen, B.S. User evaluation of the urban park design implementation with participatory approach process. Procedia-Soc. Behav. Sci., 216 (2016), pp. 306-315. 
186. Ulmer, J.M., Wolf, K.L., Backman, D.R., Tretheway, R.L., Blain, C.J.A., O'Neil-Dunne, J. P.M., Frank, L.D. Multiple health benefits of urban tree canopy: The mounting evidence for a green prescription. Health and place, Vol, 42, 2016, pp. 54-62. https://doi.org/10.1016/j. healthplace.2016.08.011.

187. Wagtendonk, A.J., Koomen, E. An indicator set for capturing long-term open space fragmentation and urban development dynamics. Computers, Environment and Urban Systems, Vol. 76, July 2019, pp. 178-193.

188. Weich, S., Burton, E., Blanchard, M., Prince, M., Sproston, K., Erens, B. Measuring the built environment: Validity of a site survey instrument for use in urban settings. Health \& Place, Vol. 7, 2001, pp. 283-292.

189. Wirth, L. Urbanism as a way of life. Am. J. Sociol., Vol. 44, 1938, pp. 1-24.

190. Zaleckis, K., Vitkuviene, J., Grazuleviciute-Vileniske, I., Tranaviciute, B., Dogan, H.A., Sinkiene, J., Grunskis, T. Public Spaces of Kaunas from the Inter-War Period to Contemporary: Content Analysis. Architecture and Urban Planning, Vol. 14, 2018, pp. 35-45. https://doi.org/10.2478/aup-2018-0005.

191. Zerouati, W. Bellal, T. Evaluating the impact of mass housings' in-between spaces' spatial configuration on users' social interaction. Frontiers of Architectural Research, Vol. 9, Issue 1, March 2020, pp. 34-53. https://doi.org/10.1016/j.foar.2019.05.005.

192. Zhang, Zh., Meerow, S., Newell, J.P., Lindquist, M. Enhancing landscape connectivity through multifunctional green infrastructure corridor modeling and design. Urban forestry and urban greening, Vol. 38, 2019, pp. 305-317. https://doi.org/10.1016/j.ufug.2018.10.014.

\section{Elektroniskie resursi}

193. Brownson, R.C., Brennan Ramirez, L.K. et al. Analytic Audit Tool and Checklist audit tool [online]. Active living research [cited 10.01.2019]. https://activelivingresearch.org/analytic-audit-tool-and-checklist-audit-tool.

194. CABE. The value of public space: How high quality parks and public spaces create economic, social and environmental value [online, cited 10.08.2019]. https://www.designcouncil.org.uk/sites/default/files/ asset/document/the-value-of-public-space1.pdf.

195. Carmona, M. Place value and the ladder of place quality. A place alliance report. 2019. 18 p. [online]. Place alliance [cited 10.10.2019]. 
http://placealliance.org.uk/wp-content/uploads/2019/03/Place-Value-and-the-Ladder-of-Place-Quality-Place-Alliance.pdf.

196. Centrālā statisktikas pārvalde. Iedzīvotāju skaits un galvenie demogrāfiskie rādītāji [tiešsaistē 01.09.2019]. https://www.csb.gov. lv/lv/statistika/statistikas-temas/iedzivotaji/iedzivotaju-skaits/ tabulas/metadati-iedzivotaju-skaits-un-galvenie.

197. CIAM (Congres Internationaux d'Architecture Moderne) [online]. Open learn [cited 10.11.2019]. https://www.open.edu/openlearn/ history-the-arts/history/heritage/ciam-congres-internationaux-darchitecture-moderne.

198. City typology [online]. European environment agency [cited 10.11.2019]. https://www.eea.europa.eu/themes/sustainability-transitions/urban-environment/sub-sections/urban-green-infrastructure/typology-for-urban-green-infrastructure.

199. Cohut, M. Simply seeing green spaces may help reduce cravings, 2019 [online]. Medical news today [cited 01.09.2019]. https://www. medicalnewstoday.com/articles/325765.

200. Common International Classification of Ecosystem Services (CICES) [online]. Biodiversity information system for Europe [cited 10.11.2019]. https://biodiversity.europa.eu/maes/common-international-classification-of-ecosystem-services-cices-classification-version-4.3.

201. Courtyard [online]. Oxford Learner's Dictionaries [cited 11.10.2019]. https://www.oxfordlearnersdictionaries.com/definition/english/ courtyard.

202. Day, K. The Irvine-Minnesota Inventory (IMI) [online, cited 20.01.2019]. https://www.midss.org/content/irvine-minnesota-inventory.

203. Duxbury, G. People don't just need social housing, they need green spaces close by [online]. The guardian [cited 10.11.2019]. https://www. theguardian.com/society/2015/jun/23/social-housing-green-spaces-health-benefits.

204. Ecosystem services categories [online]. Biodiversity information system for Europe [cited 10.11.2019]. https://biodiversity.europa. $\mathrm{eu} / \mathrm{maes} / \mathrm{ecosystem-services-categories-in-millennium-ecosys-}$ tem-assessment-ma-the-economics-of-ecosystem-and-biodiversity-teeb-and-common-international-classification-of-ecosystem-services-cices.

205. Elledge, J. British governments used to cough up for social housing. Not this one, 2018 [online]. The guardian [cited 10.11.2019]. https:// www.theguardian.com/commentisfree/2018/mar/02/british-governments-social-housing-councils-residents. 
206. Environmental protection agency. Environmental quality Index [online, cited 10.11.2019]. https://www.epa.gov/healthresearch/environmental-quality-index-eqi.

207. European commission. A walk to the park: Assessing access to green areas in Europe's cities, 2018 [online, cited 10.11.2019]. https:// ec.europa.eu/regional_policy/sources/docgener/work/2018_01_ green_urban_area.pdf.

208. European environment agency. Annex 3: European common indicators: Towards a local sustainability profile [online, cited 10.11.2019]. https://www.eea.europa.eu/publications/ environmental_issue_report_2002_30/chap10-annex3.pdf/view.

209. Gedge, D. Green infrastructure and housing estates [online]. Green infrastructure [cited 10.11.2019]. https://greeninfrastructureconsultancy.com/green-infrastructure-social-housing/.

210. Gedge, D. Retrofitting green infrastructure around housing estate [online]. Green infrastructure [cited 10.11.2019]. https://greeninfrastructureconsultancy.com/retrofitting-green-infrastructure/.

211. Gooden, B. A green view: how seeing trees from your window improves wellbeing. City Green Urban Landscape solutions, 2019 [online]. City Green [cited 10.02.2019]. https://citygreen.com/blog/agreen-view-how-seeing-trees-from-your-window-improves-wellbeing/.

212. Housing in Köln Ostheim : Urbane Gestalt [online]. Landezine [cited 10.11.2019]. http://landezine.com/index.php/2015/02/housing-inkoln-ostheim-complete-renewal-of-a-1950s-housing-complex/.

213. Iedzīvotāju aptauja par dzīvi apkaimē 4. Ziepniekkalns [tiešsaiste]. Rìgas domes pilsētas attīstības departaments [skatīts 10.09.2018]. https://www.rdpad.lv/wp-content/uploads/2014/12/4_apkaime_ Ziepniekkalns_atskaite.pdf.

214. Iedzīvotāju aptauja par dzīvi apkaimē 9. Jugla [tiešsaiste]. Rïgas domes pilsētas attīstības departaments [skatīts 10.09.2018]. https://www. rdpad.lv/wp-content/uploads/2014/12/9_apkaime_Jugla_atskaite. pdf.

215. IEREK International experts for Research enrichment and knowledge exchange (2016). The compact city a sustainable urban form [online]. IEREK [cited 10.11.2019]. https://www.ierek.com/news/index. php/2016/08/03/compact-city-sustainable-urban-form/.

216. Imantas iedzīvotāju vērtējums dzīvei apkaimē. Imantas iedzīvotāju aptauja. 2012. gada decembris - 2013. gada janvāris. Tirgus un sabiedriskās domas pētījumu centrs, 26 lpp. [tiešsaistē 10.09.2018]. https://sus.lv/sites/default/files/media/faili/atskaite_ imanta_12_2012.pdf. 
217. Importance of Leisure \& Recreation for Health [online]. Entertainment Broadcast [cited 10.11.2019]. http://broadcastforfriends.com/importance-leisure-recreation-health/.

218. Izsludināts Rīgas pilsētas apkaimju attīstības projektu īstenošanas konkurss [tiešsaistē]. Riga.lv [citēts 20.04.2019]. https://www.riga.lv/ lv/news/izsludinats-rigas-pilsetas-apkaimju-attistibas-projektu-istenosanas-konkurss?16775.

219. Knowledge [online]. Biodiversity information system for Europe [cited 10.11.2019]. https://biodiversity.europa.eu/research.

220. Leipzig Charter on Sustainable European Cities, 2 May 2007, 7 p. [online, cited 10.11.2019]. https://ec.europa.eu/regional_policy/ archive/themes/urban/leipzig_charter.pdf.

221. Listova. E. Sovetskaya imperiya. Khrushevki. TV Channel "History" = Советская империя. Хрущевки | Телеканал «История» [онлайн, просмотрено 10.04.2020]. https://www.youtube.com/ watch?v=LyideCu4LFk.

222. London infrastructure plan 2050 [online]. London.gov.uk [cited 10.11.2019]. https://www.london.gov.uk/what-we-do/ better-infrastructure/infrastructure-policies/london-infrastructure-plan-2050.

223. Muhs, A. [online, cited 10.11.2019]. http://www.muhs.de/ galerie/details.php?image_id=47206\&sessionid=20b2a7333ae2cc106e5455203453aac3.

224. Nāc un piedalies pagalma labiekārtošanā Zolitūdē, Sarkandaugavā un Maskavas priekšpilsētā [tiešsaistē]. Rīgas domes pilsētas attīstības departaments [citēts 10.04.2020]. https://www.rdpad.lv/nac-un-piedalies-pagalma-labiekartosana-zolitude-sarkandaugava-un-maskavas-priekspilseta/.

225. "Neues bauen" ("Modern Architecture") and Greening (-1920 today) [online]. Fassaden Gruen [cited 15.11.2019]. https://www. fassadengruen.de/en/bauhaus-modern-building.html.

226. Par iniciatīvu: konkursa rezultāti [online]. BalsoRíga.lv [cited 5.11.2019]. https://balso.riga.lv/par-iniciativu.

227. Pikora, T. Systematic Pedestrian and Cycling Environmental Scan (SPACES) [online, cited 10.11.2019]. https://activelivingresearch. org/systematic-pedestrian-and-cycling-environmental-scan-spaces-instrument. 
228. Projektu konkursa „Apkaimju iniciatīvas līdzdalības un piederības veicināšanai, 3. uzsaukums, 2018. gada 17. septembrī [tiešsaiste]. Riga City Council Department of Education, Culture and Sport [skatìts 10.01.2019]. https://integracija.riga.lv/lv/integracija?target=news_ item\&news_item=projektu-konkursa-apkaimju-iniciativas-lidzdalibas-un-piederibas-veicinasanai-3-uzsaukums-1059.

229. Quality of life [online]. European commission [cited 10.11.2019]. https://ec.europa.eu/eurostat/cache/infographs/qol/index_en.html.

230. Reestructuració del conjunt de Hellersdorf Berlin (Germany) Integral urban regeneration of a housing development in the northeast periphery of Berlin [online]. Public Space [cited 10.11.2019]. https://www.publicspace.org/works/-/project/ w001-reestructuracio-del-conjunt-de-hellersdorf.

231. Restructuring large-scale housing estates in European cities: good practices and new visions for sustainable neighbourhoods and cities [online]. European commission [cited 01.10.2018]. https://cordis. europa.eu/project/id/EVK4-CT-2002-00085.

232. Rīgas attīstības stratēgija līdz 2030. gadam [skatīts 10.01.2019]. https://www.rdpad.lv/wp-content/uploads/2014/11/STRATEGIJA_ WEB.pdf.

233. Rīgas domes izglītības, kultūras un sporta departaments. Imantas un Mežciema apkaimēs jauni sporta un aktīvās atpūtas laukumi [skatīts 10.01.2020]. https://sports.riga.lv/lv/sports?news_ item=imantas-un-mezciema-apkaimes-jauni-sporta-un-aktivas-atputas-laukumi-999\&target=news_item.

234. Rīgas domes pilsētas attīstības departaments. Pārskata "2017. Gada pārskats par Rīgas ilgtspējīgas attīstības stratēgijas līdz 2030. gadam un Rīgas attīstības programmas 2014.-2020.gadam ieviešanu" gala atskaite [skatīts 10.01.2019]. https://sus.lv/sites/ default/files/media/faili/parskats2017_nr1771.pdf.

235. Salastie, R. Pihlajamäki Residential Area Several architects [online]. Docomomo Finland [cited 10.10.2019]. https://en.docomomo.fi/ projects/pihlajamaki-residential-area/.

236. Share of green urban areas [online]. ArcGIS [cited 10.11.2019]. https://eea.maps.arcgis.com/apps/MapSeries/index.html?appid=42bf8cc04ebd49908534efde04c4eec8\%20\&embed=true.

237. STSM Reports. COST Action TU 1201 Urban Allotment Gardens in European $\mathrm{Ci \theta}$ es Future, Challenges and Lessons Learned [online]. Urban Allotments [cited 1.03.2021]. https://www.urbanallotments. eu/stsm/reports-2015.html.

238. Sustainability [online]. Sweden.se [cited 12.05.2019]. https://sweden. se/climate/sustainability. 
239. Thamesmead [online]. BBC Home [cited 10.11.2019]. http://www. bbc.co.uk/insideout/content/articles/2008/10/08/london_ thamesmead_s14_w4_feature.shtml.

240. The future of cities [online]. European commission [cited 10.11.2019]. https://ec.europa.eu/futurium/en/system/files/ged/ the-future-of-cities_online.pdf.

https://urban.jrc.ec.europa.eu/thefutureofcities/the-citizenscity\#the-chapter

241. The international CPTED Association [cited 10.11.2019]. https://www. cpted.net/.

242. The Revised Residential Environment Assessment Tool (REAT 2.0) [online]. Residential Environment Assessment Tool data site [cited 10.11.2019]. http://reat.cardiff.ac.uk/.

243. The RESIDential Environments (RESIDE) [online]. The university of Western Australia [cited 10.11.2019]. https://www.science.uwa.edu. $\mathrm{au} / \mathrm{centres} / \mathrm{cbeh} /$ projects/reside.

244. The University of Maryland Urban Design Tool [online]. School of architecture, planning and preservation [cited 10.11.2019]. https:// arch.umd.edu/programs/urban-studies-and-planning.

245. Vectorstock [cited 10.11.2020]. https://www.vectorstock.com/ royalty-free-vector/europe-gray-map-vector-25870102.

246. Walking strategy for Winchester. Promoting walking as a prime mode of transport [online, cited 10.11.2019]. https://www.winchester.gov. uk/assets/attach/1261/Walking-Strategy-for-Winchester-2-.pdf.

247. What is green infrastructure? [online]. European environmental agency [cited 10.11.2019]. https://www.eea.europa.eu/themes/sustainability-transitions/urban-environment/urban-green-infrastructure/ what-is-green-infrastructure.

248. World Health organization. Global recommendations on physical activity for health, 2010. 58 p. [online]. World Health organization [cited 10.11.2019]. https://www.who.int/dietphysicalactivity/ publications/9789241599979/en/.

\section{Promocijas darbi}

249. Heeger, H. Aanpak Van Naoorlogse Probleemcomplexen (Dealing with post-war housing estates). Delft: Delftse Universitaire Pers, 1993. $417 \mathrm{p}$.

250. Īle, U. Dzīvojamo rajonu iekškvartālu ainaviskā kvalitāte Latvijas pilsētās. Jelgava: Latvijas Lauksaimniecības universitāte, 2011.

251. Legeby, A. Patterns of co-presence: Spatial configuration and social segregation. Stockholm: Royal institute of technology, 2013. 
252. McCrea, R. Urban Quality of Life: Linking Objective Dimensions and Subjective Evaluations of the Urban Environment. School of geography, planning and architecture, University of Quinsland, Australia, PhD Thesis, 2007.

253. Stjernberg, M. Concrete Suburbia: Suburban housing estates and socio-spatial differentiation in Finland. Project: Small and medium-sized cities in the Nordic and Arctic regions. University of Helsinki: Department of Geosciences and Geography, 2019. https://doi. org/10.13140/RG.2.2.21767.14242.

254. Treija, S. Dzīvojamas vides attīstība Rīgā. Rīga: Rīgas Tehniskā universitāte, 2006.

255. Wassenberg, F. A. G. Large Housing Estates: Ideas, Rise, Fall and Recovery: The Bijlmermeer and Beyond. Contributor: H. Priemus. TU Delft, OTB Research institute for the built environment. 2013. https:// doi.org/10.4233/uuid:667bb070-f469-442b-8d72-54c61f61d884.

\section{Normativi akti un citi dokumenti}

256. Ministru kabineta noteikumi Nr. 340. Noteikumi par Latvijas būvnormatīvu LBN 211-15 "Dzīvojamās ēkas" [skatīts 14.02.2020]. https://likumi.lv/ta/id/275016-noteikumi-par-latvijas-buvnormativu-lbn-211-15-dzivojamas-ekas-.

257. Par zemes reformu Latvijas Republikas pilsētās. Latvijas Republikas likums [tiešsaiste, skatīts 10.10.2018]. https://likumi.lv/doc. php?id=70467.

258. Tematiskie plānojumi. Jaunā Rīgas teritorijas plānojuma līdz 2030. gadam izstrādes ietvaros [tiešsaiste]. Rīgas domes Pilsētas attīstības departaments [skatīts 10.10.2020]. https://www.rdpad.lv/rtp/ tematiskie-planojumi/.

259. Rīgas ilgtspējīgas attīstības stratēǵija līdz 2030.gadam [tiešsaiste]. Rìgas domes Pilsētas attīstības departaments [skatīts 10.10.2020]. https://www.rdpad.lv/strategija/.

260. Rīgas teritorijas plānojums 2006.-2018. gadam gadam [tiešsaiste]. Rìgas domes Pilsētas attīstības departaments [skatīts 10.10.2020]. https://www.rdpad.lv/rtp/speka-esosais/.

261. Roze, A. Rìgas telpiskās kompozīcija attīstība. Pētniecības darbs izstrādāts saskan,ā ar 2004. gada 14. jūnija līgumu Da-04-181-li. 58 lpp.

Nepublicētie materiāli

262. Latvijas arhitektūras muzeja arhīva materiāli. 


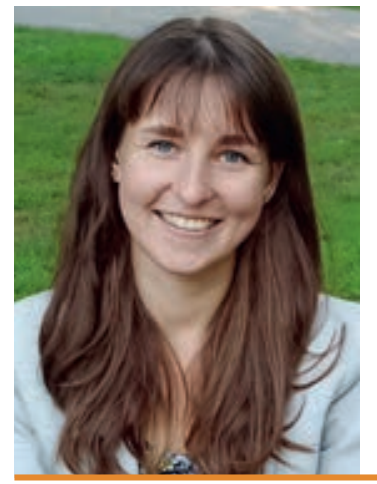

Alisa Koroḷova ieguvusi arhitekta kvalifikāciju un inženierzinātṇu maǵistra grādu arhitektūrā Rịgas Tehniskajā universitātē (RTU). Šobrīd ir RTU Arhitektūras fakultātes pētniece un asistente studiju darbā. Kopš 2015. gada ir RTU zinātniskā žurnāla "Architecture and Urban Planning" redaktore. Sākot no 2020. gada, žurnāls ir iekḷuts Scopus datubāzē. Kopš 2016. gada piedalās RTU starptautiskās zinātniskās konferences sekcijas "Arhitektūra un pilsētplānošana" organizēšanā, kā arī Baltijas valstu doktorantu semināru un vieslekciju organizēšanā. A. Korolova piedalijusies COST Action TU1201 Urban Allotment Gardens in European Cities Future, Challenges and Lessons Learned (2012-2016) starptautiskajā sadarbības projektā. Pašlaik ir COST Action CA17133 Implementing Nature-Based Solutions for Creating a Resourceful Circular City (2018-2022) vadības komitejas locekle un darba grupas "Built environment" dalībniece, kā arī COST Action CA18204 Dynamics of Placemaking and Digitization in Europe's Cities (2019-2023) vadības komitejas locekle. Viṇa ir Latvijas-Lietuvas-Taivānas sadarbības projekta "Up-to-date Information Systems in Urban Regeneration" (2020-2022) un Nordplus Adult 2021 projekta Urban Garden Specialist (2021-2023) pētniece. Kopš 2016. gada publicējusi vairākus zinātniskos rakstus un piedalījusies ar ziṇojumiem vietējās un starptautiskās konferencēs un doktorantu semināros. 